\title{
From Breard to Medellin: Supreme Court Inaction or ICJ Activism in the Field of International Law?
}

\author{
Mani Sheik $\dagger$
}

\section{INTRODUCTION}

Every first-year law student learns that the law evolves slowly over a long period of time. But sometimes, the law progresses more quickly.

The rapidly evolving jurisprudence involving U.S. violations of international treaty obligations for consular rights to foreign nationals provides the latest example of how the legal landscape can change overnight. Just a few years ago, when it first encountered this topic, the U.S. Supreme Court denied a Paraguayan man's last-minute appeal as he was about to be executed, despite violations of his consular rights. ${ }^{1}$ In Breard v. Greene, the Court declared its hands tied, and found that only the state governor could intervene to stop the execution. ${ }^{2}$

In less than a decade, the International Court of Justice (ICJ) has issued three separate, and increasingly strongly-worded rulings finding that the United States has violated its international obligations under the Vienna Convention on Consular Relations (VCCR). Simultaneously, numerous federal and state courts have addressed these same issues, seeking to reconcile the Supreme Court's refusal to enter the fray in Breard with the ICJ's deliberate holdings on the matter.

As a matter of course, at both international and domestic levels, the U.S. executive branch apologizes for the VCCR violations, and usually provides assurances that such violations will not occur in the future. Yet, violations do continue. Furthermore, courts often refuse to require new trials or resentencing for VCCR violations, finding sufficient the executive's apologies and assurances. These apologies and assurances, and the courts'

Copyright $\odot 2006$ California Law Review, Inc. California Law Review, Inc. (CLR) is a Califomia nonprofit corporation. CLR and the authors are solely responsible for the content of their publications.

$\dagger \quad$ J.D. Candidate, School of Law, University of Califomia, Berkeley (Boalt Hall), 2006; B.S., University of Califomia, Irvine; M.P.H., Johns Hopkins School of Public Health. The author would like to thank John Yoo, William Fletcher, Peter Honigsberg, and the Califomia Law Review's student editors for their valuable comments and insights. I also thank my family for their support.

1. Breard v. Greene, 523 U.S. 371,373 (1998) (per curiam).

2. Id. at 378 . 
usual failure to intervene, provide inadequate remedies to those whose rights have been violated.

Among those rights violated are consular rights-citizens' rights to notify and potentially receive legal assistance from their country's consulate in the event of their detention-which the VCCR guarantees to its signatory states and their citizens. U.S. citizens rely on these rights for protection when traveling abroad. Yet, consular rights violations occur frequently in the United States, infringing on the procedural rights of perhaps thousands of foreign nationals, including many on death row.

How foreign nationals exercise their rights in U.S. courts remains unclear and in flux. Many U.S. courts have held that the VCCR does not convey individually enforceable rights. ${ }^{3}$ Further, these courts uphold procedural default rules, under which a defendant loses the opportunity to claim a violation of his consular rights on appeal in federal court if he fails to raise the matter first in state courts. Both rulings directly violate ICJ holdings. Further, most U.S. courts refuse to provide a reasonable remedy for VCCR violations. ${ }^{4}$

In its 2004 term, the Supreme Court granted certiorari in a case squarely confronting many of these issues. ${ }^{5}$ The Court's Medellin order addressed: 1) whether a U.S. court must apply the ICJ's holding that U.S. courts "must review and reconsider the national's conviction and sentence, without resort to procedural default doctrines," and 2) whether a U.S. court should "give effect to [ICJ] Judgments as a matter of international judicial comity and in the interest of uniform treaty interpretation."

But in a series of last-minute maneuvers that would have impressed Machiavelli himself, the Bush administration effectively removed the case from the Court's calendar. The week before oral arguments, President Bush withdrew from the VCCR's Optional Protocol. ${ }^{7}$ Shortly thereafter, Bush signed an order guaranteeing the United States would discharge its international obligations under previous ICJ rulings. ${ }^{8}$ Faced with these developments, the Court recently dismissed certiorari as improvidently granted to allow for lower courts to address the new issues raised by the Bush maneuvers. ${ }^{9}$

3. See infra Part II.B.3.ii.

4. See infra Parts II.B.3.iv and II.C.2.iii.

5. Medellin v. Dretke (Medellin I), 371 F.3d 270 (5th Cir.), cert. granted, I25 S. Ct. 686 (2004).

6. Questions Presented, Medellin v. Dretke (Medellin II), 125 S. Ct. 2088 (2005) (per curiam), available at http://www.supremecourtus.gov/qp/04-05928qp.pdf.

7. Letter from Condoleeza Rice, U.S. Sec'y of State, to Kofi Annan, U.N. Sec'y Gen. (Mar. 7, 2005) (withdrawing from the VCCR).

8. Memorandum from George W. Bush to the Attomey General (Feb. 28, 2005) (on file with author), available at http://www.law.miami.edu/ froomkin/intl05/medellin-sg-app-i-ii.pdf. These machinations will be discussed in detail later, infra Part II.D.2.

9. Medellin II, I25 S. Ct. at 2089. 
The Court's dismissal did not end the matter, however. In its 2005 term, the Court granted certiorari review in two cases involving VCCR violations. ${ }^{10}$ The Court will soon address the nature of VCCR rights, whether domestic procedural rules bar VCCR claims, and which remedies may be available for defendants whose VCCR rights have been violated. ${ }^{11}$ How the Court ultimately rules in these cases will provide guidance to both state and federal courts as they search for uniform standards to apply in the numerous claims of VCCR violations before them. The Court's decision will also inevitably affect international relations, an area in which the Court may feel uncomfortable.

The Court need not be the lone branch to engage the VCCR's consular notification requirements though. Each branch of government can adopt various methods to protect consular rights. These include the following: Miranda-like advisories adopted by Congress and state legislatures to bring their respective jurisdictions into VCCR compliance; federal legislation exempting VCCR violations from the procedural default doctrine; and state or federal statutes (as exemplified by California) that comply with ICJ orders by requiring officials to notify a detainee of his consular rights "without delay" (perhaps as quickly as two hours after his arrest). Further, the President and governors can exercise their clemency powers to remedy VCCR violations.

Part I of this Comment argues that VCCR violations merit attention because potentially thousands of foreign nationals accused of crimes in the United States, many seated on death row, are denied a source of legal assistance guaranteed by international accord. Part II addresses the history of VCCR cases, both nationally and internationally, beginning with Breard, continuing through the ICJ's important cases interpreting the VCCR, and ending with the recent Supreme Court decision in Medellin. These cases paint contrasting images of an ICJ that grows bolder in its judgments and a Supreme Court that looks to evade these thorny issues. Perhaps by taking VCCR claims in successive terms, the Court has finally begun a shift away from its previous inaction. Part III presents options for addressing these violations, including I) actions the United States can take to prevent future violations, as well as 2) actions the United States should take to address those violations of consular rights that have already occurred.

10. Questions Presented, Sanchez-Llamas v. Oregon, No. 04-10566 (U.S. Nov. 7, 2005) (granting certiorari to decide the following questions: " 1 . Does the [VCCR] convey individual rights of consular notification and access to a foreign detainee enforceable in the Courts of the United States? 2. Does the state's failure to notify a foreign dctainee of his rights under the [VCCR] result in the suppression of his statements to police?), Bustillo v. Johnson, No. 05-51 (U.S. Nov. 7, 2005) (granting certiorari to decide the following questions: "Whether, contrary to the [ICJ's] interpretation of the [VCCR], state courts may refuse to consider violations of Article 36 of that treaty because of a procedural bar or because the treaty does not create individually enforceable rights," available at http://www.supremecourtus.gov/qp/04-10566qp.pdf.

11. Id. 
I

\section{Consular Rights in the United States}

\section{A. The Vienna Convention on Consular Rights: An Overview}

The Vienna Convention on Consular Relations and the Optional Protocol concerning the compulsory settlement of disputes at the $\mathrm{ICJ}^{12}$ are binding multinational treaties adopted in 1963 and ratified by the U.S. Senate in $1969 .{ }^{13}$ Currently, 168 nations have signed on to the VCCR and its Optional Protocol. ${ }^{14}$ Article 5 of the VCCR establishes consuls ${ }^{15}$ for signatory states, whose duties include assisting their foreign nationals and, "subject to the practices and procedures [of] the receiving State, representing or arranging appropriate representation" for foreign nationals before tribunals and other authorities of the receiving State. ${ }^{16}$

VCCR Article 36 addresses communication and contact with foreign nationals and states:

1. With a view to facilitating the exercise of consular functions relating to nationals of the sending State:

(a) consular officers shall be free to communicate with nationals of the sending State and to have access to them. Nationals of the sending State shall have the same freedom with respect to communication with and access to consular officers of the sending State;

(b) if he so requests, the competent authorities of the receiving State shall, without delay, inform the consular post of the sending State if, within its consular district, a national of that State is arrested or committed to prison or to custody pending trial or is detained in any other manner. Any communication addressed to the consular post by the person arrested, in prison, custody or detention shall also be forwarded by the said authorities without delay. The said authorities shall inform the person concerned without delay of his rights under this sub-paragraph;

(c) consular officers shall have the right to visit a national of the sending State who is in prison, custody or detention, to converse and correspond with him and to arrange for his legal

12. Vienna Convention on Consular Relations, Apr. 24, 1963, 21 U.S.T. 77, 596 U.N.T.S. 261 [hereinafter VCCR].

13. 115 Cong. Rec. S30997 (daily ed. Oct 22, 1969). The Optional Protocol grants the ICJ jurisdiction to settle disputes arising from interpretations of the Convention. Thus, because of Bush's withdrawal from the Optional Protocol, the ICJ now lacks jurisdiction to address any future claims of VCCR violations brought against the United States.

14. Available at http://untreaty.un.org/ENGLISH/bible/englishinternetbible/partl/chapterIII/ treaty31.asp (last visited Jan. 22, 2005).

15. A consul is defined as "[a] public official residing in a foreign country responsible for developing and protecting the cconomic interests of his government and looking after the welfare of his government's citizens who may be travelling or residing within his jurisdiction." Black's Law Dictionary 166 (5th ed. 1983).

16. VCCR, supra note 12, at art. 5(i). 
representation. They shall also have the right to visit any national of the sending State who is in prison, custody or detention in their district in pursuance of a judgment. Nevertheless, consular officers shall refrain from taking action on behalf of a national who is in prison, custody or detention if he expressly opposes such action.

2. The rights referred to in paragraph 1 of this Article shall be exercised in conformity with the laws and regulations of the receiving State, subject to the proviso, however, that the said laws and regulations must enable full effect to be given to the purposes for which the rights accorded under this Article are intended. ${ }^{17}$

The VCCR codified existing international norms regarding consular relations and established new standards in the field. As such, the VCCR binds all States to the former through customary international law and binds signatory States, including the United States, to the latter by way of accession to the treaty.

In the United States, VCCR claims generally arise because of federal and state officers' failures to "inform the consular post"18 when its national is arrested, and/or to do so "without delay," in violation of Article $36(1)(b) .{ }^{19}$ In international adjudication, Article 36(1)(c)'s language confers upon States the right to bring suits for violations of their rights. Thus, the VCCR follows the "diplomatic protection" 20 model of international law where a State represents its national in a foreign court. ${ }^{21}$

Many U.S. courts agree that the VCCR is a self-executing treaty ${ }^{22}$ that is binding on states via the Supremacy Clause. ${ }^{23}$ But a self-executing treaty does not necessarily give rise to a private right of action. ${ }^{24}$ Problems arise, therefore, in deciding 1) whether the VCCR conveys an individual right that can be enforced in United States courts, and 2) what remedies, if any, are available for violations of VCCR rights.

17. VCCR, supra note 12 , at art. 36.

18. Id.

19. See id.

20. For the definition of "diplomatic protection," see generally 1 ENCYCLOPEDIA of Public INTERNATIONAL LAW 1045-67 (1992).

21. Id.

22. See United States v. Chaparro-Alcantara, 37 F. Supp. 2d 1122, 1124 n.1 (C.D. 111. 1999), affd, 226 F.3d 616 (7th Cir. 2000); United States v. Torres-Del Muro, 58 F. Supp. 2d 931, 932 (C.D. 111. 1999); Breard v. Pruett, 134 F.3d 615, 621 (4th Cir. 1998) (Butzner, J. concurring) (citing Faulder v. Johnson, 81 F.3d 515, 520 (5th Cir.1996)).

23. U.S. CONST, art. VI, cl. 2 ("[A]ll Treaties made, or which shall be made, under the Authority of the United States, shall be the supreme Law of the Land; and the Judges in every State shall be bound thereby, any Thing in the Constitution or Laws of any State to the Contrary notwithstanding.").

24. See Medellin II, $125 \mathrm{~S}$. Ct. at 2103 (2005) (O'Connor, J., dissenting) ("To be sure, the questions of whether a treaty is self-executing and whether it creates private rights and remedies are analytically distinct."). 


\section{B. Persons Whose Consular Rights Are Potentially Abridged in the United States}

As of May 28, 2005, an estimated 118 foreign nationals awaited execution in sixteen U.S. state and federal prisons. ${ }^{25}$ The recent $1 \mathrm{CJ}$ decision in Avena ${ }^{26}$ covers nearly half of these 118 foreign nationals and may realistically extend to the other half given the language of the ICJ's decision. ${ }^{27}$ Yet, this figure may vastly under-represent the actual number of foreign nationals awaiting execution in the United States. For example, in its memorial in Avena, Mexico noted that a separate, comprehensive survey of its U.S. consulates identified "no fewer than 102 cases of Mexican nationals detained on serious criminal charges after 27 June 2001, none of which were [sic] notified of their Article 36 rights." 28 Of these, eighty-nine were homicide charges, and thirty-six were eligible for the death penalty. ${ }^{29}$ It is nearly impossible to cxtrapolate from this single internal investigation how many individuals actually face criminal, homicide or capital charges. The results, however, appear to contradict U.S. assertions that the issue of consular relations is being adequately remedied at the domestic level. ${ }^{30}$

The U.S. Census Bureau reported that 18.5 million non-citizens lived in the United States at the time of the 2000 census, accounting for $6.6 \%$ of the total population. ${ }^{31}$ This figure does not come close to reflecting the millions of visitors and tourists who come to the United States for short periods each year. Any one of these foreigners can be swept into the American criminal justice system. All would be entitled to VCCR rights.

25. Mark Warren, Human Rights Research, Foreign Nationals and the Death PENALTY IN THE UNITED STATES (2005), available at http:/www.deathpenaltyinfo.org/ article.php?did=198\&scid=31.

26. Case Concerning Avena and Other Mexican Nationals (Avena) (Mex. v. U.S.), 2004 1.C.J. 128 (Mar. 31) (applying to fifty-one Mexicans on U.S. death rows). Mexico sued the United States on behalf of fifty-four of its nationals on death row. The ICJ found the United States violated the VCCR rights of fifty-one of the fifty-four plaintiffs and ordered review and reconsideration of their cases in U.S. courts. For a more in-depth discussion of the case, see infra Part Il.C.

27. Id. II I5I. ("[T] he fact that in this case the Court's ruling has concerned only Mexican nationals cannot be taken to imply that the conclusions reached by it in the present Judgment do not apply to other foreign nationals finding themselves in similar situations in the United States.")

28. Mexican Memorial, 20 June 2003, available at http://www.icj-cij.org/icjwww/idocket/ imus/imuspleadings/imus_ipleadings_20030620_memorial_03.pdf, at para. 161.

29. Id. While Avena addresses only capital defendants, its implications reach beyond capital cases because VCCR violations are not limited solely to capital crimes.

30. See infra notes 147-148 and accompanying text, noting that in an earlier 2001 case before the ICJ regarding VCCR violations, the United States insisted it was working with local and national law enforcement officials to improve VCCR compliance. Thus, the memorial's reference to 102 further violations since that time suggest that though they may have been somewhat effective, the education efforts were not fully effective in stopping VCCR violations.

3I. U.S. Census Bureau, Profile of General Demographic Characteristics: 2000 tbl.DPI (2000), available at http://factfinder.census.gov/servlet/QTTable?_bm=y\&-geo_id=01000US\&qr_name=DEC_2000_SF1_U_DP1\&-ds_name=DEC_2000_SF1_U. 
State and federal prisons held nearly 1.5 million inmates in $2003 .^{32}$ The combined prison populations of California, New York, and Arizona number more than $250,000,{ }^{33}$ of which non-citizens account for more than $10 \% .{ }^{34}$ Nationwide, more than 90,000 non-citizens are being held in state and federal prisons. ${ }^{35}$ Thus, the number of foreign nationals in U.S. prisons whose VCCR rights may potentially be violated thus stretches into the tens of thousands.

II

A Case History of Consular Rights in the International Court of JUSTICE AND U.S. COURTS

A. Breard

The ICJ first addressed VCCR violations in Case Concerning the Vienna Convention on Consular Relations, ${ }^{36}$ often referred to as the Breard Order after the real defendant in the case.

\section{Background}

Angel Francisco Breard, a Paraguayan citizen, was sentenced to death for the 1992 rape and murder of a Virginia woman. ${ }^{37}$ At trial, the state presented "overwhelming evidence of guilt," including Breard's semen and hairs on the victim. ${ }^{38}$ Against counsel's advice, Breard took the stand and admitted to the killing, though he explained that he acted because of a satanic curse placed on him by his father-in-law. ${ }^{39}$ Some argue that, had he been notified of his consular rights and allowed to talk to Paraguayan officials, Breard might have been persuaded to plead guilty and accept a life sentence. ${ }^{40}$

State appellate courts affirmed Breard's conviction, and the U.S. Supreme Court denied certiorari. ${ }^{41}$ A few months before his execution, Breard filed a motion for habeas relief in federal court, raising a VCCR claim for the first time. ${ }^{42}$ The district court found, and the Fourth Circuit

32. Paige M. Harrison \& Jennifer C. Karberg, DeP'T of Justice, Prison and Jail Inmates AT MIDYEAR 20034 (2004), available at http://www.ojp.usdoj.gov/bjs/pub/pdf/pjim03.pdf.

33. Id.

34. Medellin II, I25 S. Ct. at 2096 (2005) (citing statistics from HARRISON \& KaRBERG, supra note 32 .

35. HARRISON \& KARBERG, supra note 32, at 1 .

36. Vienna Convention on Consular Relations (Para. v. U.S.) (Breard Order), 1998 I.C.J. 248 (Apr. 9).

37. Breard v. Greene, 523 U.S. 37I, 373 (1998).

38. Id.

39. Id.; David Stout, Clemency Denied, Paraguayan Is Executed, N.Y. Tımes, Apr. 15, I998, at A18.

40. Stout, supra note 39.

41. Breard, 523 U.S. at 373.

42. Id. 
later agreed, that Breard had procedurally defaulted on his claim by not raising it in state court. ${ }^{43} \mathrm{~A}$ parallel suit, brought by the Republic of Paraguay (Paraguay) against certain Virginia officials and alleging similar VCCR violations, was rejected by both the district court and the Fourth Circuit. $^{44}$

Two weeks before Breard's scheduled execution, Paraguay instituted proceedings against the United States in the ICJ. ${ }^{45}$ The ICJ noted jurisdiction and issued a Provisional Measures Order (PMO or Provisional Order $)^{46}$ stating that " $[\mathrm{t}]$ he United States should take all measures at its disposal to ensure that Angel Francisco Breard is not executed pending the final decision in these proceedings, and should inform the Court of all the measures which it has taken in implementation of this Order." 97 Breard then individually filed a petition for leave to file a bill of complaint with the United States Supreme Court to "enforce" the PMO. ${ }^{48}$

\section{U.S. Government Response}

Though adopting divergent strategies, the U.S. Departments of Justice and State both urged the Supreme Court to deny Breard's appeal. The Office of the Solicitor General (OSG) asserted that the alleged treaty violation did not justify giving Breard a new trial. ${ }^{49}$ The State Department, agreeing that the Supreme Court had no legal basis to stop the execution, noted the important diplomatic aspect of the case and that then Secretary of State Madeline Albright was appealing to Virginia Governor James Gilmore, who alone had the ability to delay the execution. ${ }^{50}$ In a letter to the Governor, Secretary Albright cited "the unique and difficult foreign policy issues" of the case, including possible effects on international reciprocity, as grounds for delaying Breard's execution. ${ }^{51}$ Secretary Albright sandwiched her request for a delay between comments noting that " $[t]$ he United States has throughout [the proceedings] vigorously defended

43. Id.

44. Id. at 374 .

45. Id.

46. Provisional Measures Orders are analogous to temporary injunctions under U.S. common law. The ICJ can issue a PMO on the request of a party or sua sponte. Here, the ICJ issued a PMO to ensure that no further damage occurred to the suing party (Paraguay). Thus, the ICJ ordered the United States to refrain from certain actions pending the final resolution of the dispute-namely, executing Breard.

47. Breard Order, 1998 I.C.J. at 258.

48. Breard, 523 U.S. at 374.

49. Brooke A. Masters, Albright Urges Va. To Delay Execution, WASH. Post, Apr. I4, I998, at B1.

50. Id.

51. Letter from Madeleine K. Albright, U.S. Sec'y of State, to the Honorable James S. Gilmore III, Governor of Va. (Apr. 13, 1998), in International LaW in Contemporary Perspective I20 (W. Michael Reisman et al. eds., 2004). 
Virginia's right to go forward with the sentence imposed," and that "[i]t is only with great reluctance that I make this request." 52

On the day of his scheduled execution, the Supreme Court denied both Breard's and Paraguay's claims, finding that "[i]t is clear that Breard procedurally defaulted his claim, if any, under the Vienna Convention by failing to raise that claim in the state courts."53 The Court held Breard's claim failed under the "subsequent in time" doctrine, where a federal statute enacted after a treaty has been ratified renders the treaty null to the extent it conflicts with the new statute. ${ }^{54}$ In 1996, Congress passed the Antiterrorism and Effective Death Penalty Act (AEDPA), which extended the doctrine of procedural defaults and denied relief for claims "[i]f the applicant has failed to develop the factual basis of a claim in State court proceedings." This rule applies to claims arising under "treaties of the United States." 56 Thus, Breard, and all others claiming VCCR violations, were not allowed to raise those claims if not initially developed in state court proceedings.

However, defendants often do not leam of their VCCR rights until many years have passed and state remedies have already been exhausted. ${ }^{57}$ Consular notification supports the fundamental interests of justice in American law by allowing for the hiring of counsel to best advise the defendant. An advocate knowledgeable about both the American legal system and the defendant's background may be better positioned to advise him. Breard exemplifies this interest, as he could have been persuaded to plead guilty and take a lesser sentence or, at the very least, to not take the stand in his own defense. Further, early consular notification may allow counsel to examine a defendant's background and present evidence of childhood abuse or trauma, which might persuade a jury to impose a lesser sentence than death during the penalty phase of the trial. ${ }^{58}$

The Court also deferred to the dual notions of federalism and separation of powers in its decision. It noted that the executive branch exercises power over foreign relations, citing Secretary Albright's letter to Governor Gilmore. ${ }^{59}$ In granting deference to these dual notions, the Court stated, "[i]f the Governor wishes to wait for the decision of the ICJ, that is his

52. Id.

53. Breard, 523 U.S. at 375.

54. Id. (citing Reid v. Covert, 354 U.S. 1, 18 (1957)).

55. 28 U.S.C. $\S 2254(\mathrm{e})(2)(2001)$.

56. 28 U.S.C. $\$ 2254$ (a) (2001).

57. See infra notes 92 and accompanying text (discussing how Arizona did not inform German citizens of their right to consular assistance for fifteen years), 163, and 164 (discussing how more than half of the Mexican citizens were not informed of their VCCR rights until aftcr the death penalty was imposed, and many more were not informed until after they had made incriminating statements or after it was too late to affect the outcomes of their trials).

58. See infra Part III.A.2.a.

59. Breard, 523 U.S. at 378. 
prerogative. But nothing in our existing case law allows us to make that choice for him." 60 In dissent, Justices Stevens and Breyer recognized Virginia's rigidity in refusing to postpone the execution date to allow for subsequent briefings. ${ }^{61}$ Justice Breyer, dissenting alone, explained that "[m]ore time would likely mean additional briefing and argument, perhaps, for example, on the potential relevance of proceedings in an international forum [like the ICJ]." ${ }^{962}$

Not surprisingly, Governor Gilmore refused to grant clemency or issue a stay. ${ }^{63}$ The Governor noted that Secretary Albright's concerns were due "great respect" and that he had given them "serious consideration." But more important to him was his duty to ensure that Virginians may "conduct their lives free from the fear of crime." ${ }^{965}$ Governor Gilmore also acknowledged that he had given weight to Justice Department briefs suggesting the ICJ "has no authority to interfere with our criminal justice system." ${ }^{.66}$ Contrary to his proclamation that his primary duty was the safety of Virginia's citizens, the Governor seemed more concerned that "to delay Mr. Breard's execution so that the [ICJ] may review th[e] matter would have the practical effect of transferring responsibility from the courts of the Commonwealth [of Virginia] and the United States to the International Court." 67

Angel Breard was executed later the same day. ${ }^{68}$ Seven months after Breard's execution, the United States rendered a formal apology for the VCCR violation and made assurances to improve its VCCR compliance. ${ }^{69}$ The apology recognized that U.S. compliance with VCCR requirements "must improve" and noted "efforts" undertaken to better educate officials of those requirements. ${ }^{70}$ The statement also recognized the critical role reciprocity plays in the Vienna Convention: "Consular notification is no less important to Paraguayan and other foreign nationals in the United States than to U.S. nationals outside the United States. We fully appreciate that the United States must see to it that foreign nationals in the United States

60. Id.

61. Id. at 379-81 (Stevens, J. and Breyer, J., dissenting).

62. Id. at 381 (Breyer, J., dissenting).

63. Jim Gilmore, Governor of Va., Statement Concerning the Execution of Angel Breard (Apr. 14, 1998), in International LaW in Contemporary Perspective 121-22 (W. Miehael Reisman et al. eds., 2004).

64. Id. at 121 .

65. Id.

66. Id.

67. Id.

68. Stout, supra note 40.

69. Press Release, James P. Rubin, Spokesman for U.S. Dep't of State, Text of Statement Released in Asuncion, Paraguay (Nov. 4, 1998), available at http://seeretary.state.gov/ www/briefings/statements/1998/ps981104.html.

70. Id. 
receive the same treatment that we expect for our citizens overseas. We cannot have a double standard."71

Accepting the apology, Paraguay asked that its case, still pending before the $1 \mathrm{CJ}$, be removed. ${ }^{72}$ Though it is doubtful that the United States would have settled for a mere apology and assurances to improve training had one of its citizens been executed overseas without access to U.S. consular support, Paraguay's acceptance of the U.S. apology may have signaled its belief in the sincerity of the U.S. claim. However, Paraguay would be the last country to take the United States at its word. ${ }^{73}$

\section{Reaction to Breard}

The Breard saga-the legal maneuvering inside the courts and out, and the domestic and international decisions the case produced-generated a great deal of commentary from within legal academia, including law review articles ${ }^{74}$ and symposia. ${ }^{75}$ But the effects of such a landmark case are often more noticeable outside courtrooms. Because cases, particularly death penalty appeals, typically take many years to work their way through the legal system, few lower court decisions can be found in the immediate aftermath of Breard that apply the Court's analysis to VCCR violation claims in capital cases. ${ }^{76}$ The lack of case law following Breard may also be attributed in part to the Supreme Court's decision in LaGrand, issued just a few months after Breard. ${ }^{77}$

\section{B. LaGrand}

In early 1999, the Federal Republic of Germany (Germany) brought suit in the ICJ on behalf of one of its citizens, Walter LaGrand, who faced

71. Id. (emphasis added).

72. Press Release, Int'l Court of Justice, Case Removed from the Court's List at the Request of Paraguay (Nov. 11, 1998), available at http://www.icj-cij.org/icjwww/idocket/ipaus/ipausframe.htm.

73. See infra Parts 11.B and 11.C.

74. See, e.g., Sanja Djajic, The Effect of International Court of Justice Decisions on Municipal Courts in the United States: Breard v. Greene, 23 Hastings InT'L \& Comp. L. Rev. 27, 30 (1999) (arguing that other solutions were possible in Breard and that "various international and domestic legal arguments could have been employed to reach a less damaging outcome"); Howard S. Schiffman, Breard and Beyond: The Status of Consular Notification and Access Under the Vienna Convention, 8 CARDozo J. INT'L \& COMP. L. 27 (2000) (examining whether any remedies exist in domestic courts for a criminal defendant alleging a VCCR violation).

75. The American Joumal of International Law devoted an Agora symposium to discuss questions the case raised. Jonathan I. Charney et al., Agora: Breard, 92 AM. J. INT'L L. (1998) 666-712; see also Carlos Manuel Vázquez, Breard, Printz, and the Treaty Power, 70 U. Colo. L. Rev. 1317 (1999); Benedict Kingsbury, Foreword: Is the Proliferation of International Courts and Tribunals a Systemic Problem?, 31 N.Y.U. J. INT'L L. \& PoL. 679 (1999) (noting the papers in that issue arose from a symposium on "The Proliferation of International Tribunals: Piecing Together the Puzzle," held at New York University Law School that summer).

76. See Consulate Gen. of Mex. v. Phillips, 17 F. Supp. 2d 1318 (S.D. Fla. 1998).

77. Federal Republic of Germany v. United States (LaGrand), 526 U.S. 1 I 1 (1999) (per curiam). 
imminent execution in Arizona ${ }^{78}$ This case is referred to as LaGrand, named after the real defendant in the case.

\section{Background}

In 1984, brothers Karl and Walter LaGrand unsuccessfully tried to rob an Arizona bank. ${ }^{79}$ After abducting the bank manager and another employee, the brothers realized that the manager could not open the bank vault because he had only half of the vault's lock combination. ${ }^{80}$ The brothers tied the victims' hands together with black electrical tape and eventually stabbed them before fleeing. ${ }^{81}$ The bank manager died as a result of the twenty-four stab wounds he received; the employee survived to testify against the brothers. ${ }^{82} \mathrm{~A}$ jury found both brothers guilty of firstdegree murder and sentenced them to death. ${ }^{83}$

Walter and Karl LaGrand were born in Germany and were German nationals when their mother moved with them to the United States, when they were still very young. ${ }^{84}$ Although they lived in the United States for the majority of their lives and were even adopted by a U.S. citizen, "they remained at all times German nationals, and never acquired the nationality of the United States." ${ }^{85}$ Perhaps because of their inconspicuous looks and lack of foreign accents, Arizona law enforcement officers did not notify the LaGrands of their VCCR rights either at the time of detention or at any time during their legal proceedings. ${ }^{86}$

Nearly fifteen years after their crime, the LaGrands were formally notified of their VCCR rights in late $1998 .{ }^{87}$ By then, the LaGrands were appealing their convictions before the Ninth Circuit. They had exhausted all available state judicial remedies-where they would have had to initially raise their VCCR claims to avoid the procedural default rule. A split Ninth Circuit panel rejected their claims, holding, "[i]t is undisputed that the State of Arizona did not notify the LaGrands of their rights under the Treaty. It is also undisputed that this claim was not raised in any state

78. Application Instituting Proceedings in the Name of the Federal Republic of Germany (F.R.G. v. U.S.), 1999 1.C.J. (Mar. 2, 1999), available at http:/www.icj-cij.org/icjwww/idocket/igus/ igusframe.htm.

79. State v. LaGrand, 734 P.2d 563, 565 (Ariz. 1987).

80. Id. at 566 .

81. Id.

82. Id.

83. Id. at 567 .

84. LaGrand Case (F.R.G. v. U.S.) (LaGrand Judgment), 2001 I.C.J. 466, 474-75 (June 27).

85. Id. at 475 .

86. Id.

87. Id. at 478 . 
proceeding. The claim is thus procedurally defaulted." 88 The panel affirmed the LaGrands' convictions and death sentences. ${ }^{89}$

In January, 1999, the Arizona Supreme Court set Karl LaGrand's execution date for February 24 of that year, to be followed one week later by his brother Walter's execution on March $3 .^{90}$ The Arizona clemency board denied both Karl and Walter's clemency pleas, preventing Arizona Governor Jane Dee Hull from granting clemency even if she were so inclined. $^{91}$

\section{ICJ and U.S. Supreme Court Action Prior to Walter LaGrand's Execution}

On February 23, the day before Karl LaGrand's scheduled execution, the Arizona Attorney General admitted that "the State of Arizona had indeed been aware since 1982 that the [LaGrands] were German nationals." Despite German "appeals for clemency and numerous diplomatic interventions . . . at the highest level," Arizona executed Karl LaGrand as scheduled the next day..$^{93}$

With this newly disclosed information, Germany quickly filed suit before the ICJ on March 2, 1999, the day before Walter's scheduled execution, asking for provisional measures to suspend the execution pending a final ruling by the ICJ. ${ }^{94}$ The next day, the ICJ unanimously issued the following Provisional Measures Order:

(a) The United States of America should take all measures at its disposal to ensure that Walter LaGrand is not executed pending the final decision in these proceedings, and should inform the Court of all the measures which it has taken in implementation of this Order;

(b) The Government of the United States of America should transmit this Order to the Governor of the State of Arizona. ${ }^{95}$

Armed with the ICJ's Order, Germany then petitioned the United States Supreme Court for a preliminary injunction against the United States and Governor Hull, seeking enforcement of the Order in U.S. courts. In a per curiam decision, the Supreme Court denied the request because of the

88. LaGrand v. Stewart, 133 F.3d 1253, 1261 (9th Cir.), cert. denied, 525 U.S. 971, reh'g denied, 525 U.S. 1050 (1998).

89. See id.

90. LaGrand Judgment, 2001 1.C.J. 466, 478 (June 27); see also Execution Dates Set for LaGrand Brothers, ARIZ. DaILY STAR, Jan. 20, 1999, at 2B.

91. LaGrand Judgment, 2001 1.C.J. at 478.

92. Request for the Indication of Provisional Measures (LaGrand Order), LaGrand Case (F.R.G. v. U.S.), 1999 1.C.J. 9, 10 (Mar. 3) [hereinafter LaGrand Order].

93. Id. at 12; see also ARiz. Dep't of Corrections, InMates ExeCuted Since 1992, at 12-13, available at http:/www.azcorrections.gov/DeathRow/ExecutedGallery.htm (last visited Nov. 4, 2005).

94. LaGrand Order, 1999 1.C.J. at 10.

95. Id. at 16 . 
"tardiness of the pleas,"96 which were filed only two hours before Walter's execution.

Justice Souter wrote separately ${ }^{97}$ to indicate that he was swayed by the Solicitor General's position, who, as in Breard, had filed a brief urging denial because "an order of the International Court of Justice indicating provisional measures is not binding and does not furnish a basis for judicial relief." 98 The brief distinguished between the United States and one state, Arizona, claiming the former may be subject to the ICJ while the latter may not. ${ }^{99}$

Not all members of the Court concurred in the denial of review, however. In dissent, Justice Breyer, joined by Justice Stevens, stated that he would grant the preliminary stay to "give [the Court] time to consider, after briefing from all interested parties, the jurisdictional and international legal issues involved, including further views of the Solicitor General, after time for study and appropriate consultation." 100

Acting in direct response to the ICJ Order of the previous day, ${ }^{101}$ the Arizona Clemency Board reversed its earlier position and voted 2-to- $\mathrm{I}$ to recommend a sixty-day reprieve to LaGrand. ${ }^{102}$ The Board's president stated, "The man's already been on death row for 17 years; what's 60 days?' .. . 'Why not give the government of Germany a chance to present their case (in world court)." grant a reprieve pending the outcome of the ICJ opinion. She refused to do so. ${ }^{104}$

Governor Hull's decision denying clemency and refusing to grant a stay noted that Walter LaGrand had enjoyed all the rights to which she felt he was entitled, and that she had a duty to uphold state laws. ${ }^{105}$ Thus, "in the interest of justice and with the victims in mind" Governor Hull allowed the execution to go forward. ${ }^{106}$

96. LaGrand, 526 U.S. at 112

97. Id. (Souter, J., concurring).

98. LaGrand Judgment, 2001 I.C.J. 466, 479 (June 27).

99. Letter from Seth P. Waxman, Solicitor Gen., to William Suter, Clerk of the U.S. Supreme Court (Mar. 3, 1999), in International LaW in Contemporary Perspective 126 (W. Michael Reisman et al. eds., 2004).

100. LaGrand, 526 U.S. at 113 (Breyer, J., dissenting).

101. Arizona Governor Refuses Deal on German Death Row Inmate, Mar. 2, 1999, available at http://www.cnn.com/US/9903/02/arizona.execution.01/.

102. German National Executed Despite Pleas From Bonn, International Court, Agence FrancePresse, Mar. 4, 1999; see also Arizona Governor Refuses Deal on German Death Row Inmate, supra note 101 .

103. Heather Urquides, Hull Denies Clemency Board Plea for LaGrand, ARIz. DAILY STAR, Mar. 3,1999 , at $1 \mathrm{~A}$.

104. Arizona Governor Refuses Deal on German Death Row Inmate, supra note 101.

105. Teaching Human Rights Onlime, Decision Day in Arizona, available at http:/homepages.uc.edu/thro/gvus/Decision.htm\#_ednref33 (last visited Nov. 20, 2005).

106. Jane Dee Hull, Governor of Ariz., Statement on the Case of Walter LaGrand (Mar. 2, 1999), in International LaW in CONTEMPORaRy Perspective 126 (W. Michael Reisman et al. eds., 2004) 
Walter LaGrand was executed as scheduled on March 3, 1999. ${ }^{107}$

\section{The ICJ Judgment Following LaGrand's Execution and Reactions by Courts and Commentators.}

Unlike Paraguay, Germany did not settle for a posthumous apology and drop its ICJ claim once its national was executed. Instead, Germany proceeded with the claim. Fifteen months after Walter LaGrand's execution, the ICJ issued a sweeping final Judgment accepting nearly all of Germany's claims against the United States. ${ }^{108}$

\section{a. The Binding Nature of Provisional Measures}

The LaGrand Judgment addressed the binding nature of ICJ provisional measures for the first time in the ICJ's seventy-five plus years of existence. ${ }^{109}$ The court held "the power to indicate provisional measures entails that such measures should be binding . . . to safeguard, and to avoid prejudice to, the rights of the parties as determined by the final judgment of the Court." 110 Any other finding "would be contrary to the object and purpose of [the statutes establishing the ICJ]."111

The ICJ then turned to U.S. attempts to comply with the Order. The PMO had called upon the United States to "take all measures at its disposal to ensure that Walter LaGrand is not executed pending the final decision in these proceedings" and to "transmit this Order to the Governor of the State of Arizona." 12 The court found that though the United States did transmit the Order, it did so in a letter that read: "In view of the extremely late hour of the receipt of the Court's Order ... no further steps were feasible." 113 This "mere transmission... without any comment, particularly without even so much as a plea for a temporary stay" was less than could have bcen

107. Christina Leonard, LaGrand Dies in State Gas Chamber: Killer Executed Despite Protests from Germany, ARIZ. REPUBlic/GAZETTE, Mar. 4, 1999, at A1; see also ARIZ. DEP'T OF CORRECTIONS, supra note 93.

108. See LaGrand Judgment, 2001 I.C.J. 466, 474-75 (June 27). The ICJ held that the U.S. program to ensure its compliance with Article 36, ๆ 1(b) "must be regarded as meeting Germany's request for a general assurance of non-repetition," despite Germany's statement that it "does not consider the so-called 'assurances' offered by the respondent" to suffice. See infra Part II.B.3.iv. The ICJ agreed with Germany on all other issues. LaGrand Judgment, 2001 1.C.J. at 513.

109. This includes the term of the ICJ's immediate predecessor, the Permanent Court of International Justice (PCIJ), in existence from 1920 to 1942.

110. Id. at 503. On the ICJ website, one can find the LaGrand briefs, arguments, and decision, as well as a link to an ICJ synopsis of its momentous holding entitled: "The Court finds, for the first time in its history, that orders indieating provisional measures are legally binding." Press Release, Int'l Court of Justice, The Court Finds that the United States has Breached its Obligations to Germany and to the LaGrand Brothers Under the Vienna Convention on Consular Relations (June 27, 2001), available at http://www.icj-cij.org/icjwww/idocket/igusframe.htm.

111. LaGrand Judgment, 2001 1.C.J. at 503.

112. LaGrand Order, 1999 I.C.J 9, 16 (Mar. 31).

113. LaGrand Judgment, 200I I.C.J. at 507. 
done to comply with the spirit of the Order. ${ }^{114}$ The court also looked unfavorably upon: 1) the Solicitor General's letter stating that the court's Order was non-binding, 2) Governor Hull's decision to proceed with Walter LaGrand's execution despite an appeal for a temporary stay from the Arizona Clemency Board, and 3) the United Statcs Supremc Court's refusal to grant a stay pending the ICJ's final decision. ${ }^{115}$ In light of these factors, the ICJ held that "the United States has not complied with the order of 3 March 1999."'16

This portion of the ICJ's Judgment may well prove to be the most important for its future. In establishing that its Orders are binding as international law, the court took a significant step toward giving its decisions teeth. But declaring provisional measures binding and enforcing those measures are two separate concepts. ${ }^{117}$ International judgments continue to lack a viable enforcement mechanism because international law, unlike domestic legal regimes, does not have an executive armed with enforcement power.

Sandy Ghandi notes that "determining that Provisional Measures are binding will not necessarily prevent States from failing to abide by such orders." 118 For example, though the United Nations Human Rights Committee has developed rules requiring mandatory compliance with provisional measures, States have routinely flaunted the rule and executed persons before final judgments are made. ${ }^{119}$ Given thcse occurrences, Ghandi wonders:

[W] hether attributing a binding force to provisional measures will persuade a State or its relevant authoritics not to execute a condemned person in violation of a mandatory Provisional Measures Order of the Court may be doubted perhaps, in the light of the LaGrand execution and the experience of the Human Rights Committee. ${ }^{120}$

Perhaps with time, states will obey the ICJ's Provisional Measures Orders due to an international "expectation of compliance" despite the absence of

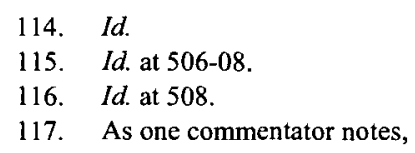

[1] $\mathrm{t}$ is still the case that most of international law is not backed up by a system of compulsory adjudication, let alone enforcement of judgments; but we international lawyers have long resisted the claims of the ignorant (and the not-so-ignorant) that lack of enforceability prevents our system from being law.

Maurice Mendelson, State Responsibility for Breach of Interim Protection Orders of the International Court of Justice, in Issues of SOcIAL RESPONSIBILITY BEFORE INTERNATIONAL JUdicial Institutions 40 (Malgosia Fitzmaurice \& Dan Sarooshi eds., 2004).

118. Sandy Ghandhi, Avena and Other Mexican Nationals (Mexico v. United States of America), Provisional Measures, Order of 5 February 2003, 53 INT'L \& COMP. L.Q. 738, 746 (2004).

119. Id.

120. Id. 
sanctions. ${ }^{121}$ Other non-legal and political avenues exist for a State to voice its displeasure with a decision while still respecting a court's authority. ${ }^{122}$ But in the short term, the ruling stands on precarious footing.

\section{b. Conferral of Individual Rights Through the VCCR}

In its final Judgment, the ICJ also rejected the U.S. contention that the VCCR does not confer individual rights on foreign nationals, ${ }^{123}$ holding that the VCCR "creates individual rights, which . . . may be invoked in this Court by the national State of the detained person." 24 Regarding the U.S. contention that VCCR rights matter only if the outcome of the case would have differed, the ICJ held:

It is immaterial... whether the LaGrands would have sought consular assistance from Germany, whether Germany would have rendered such assistance, or whether a different verdict would have been rendered. It is sufficient that the [VCCR] conferred these rights, and that Germany and the LaGrands were in effect prevented by the breach of the United States from exercising them, had they so chosen. ${ }^{125}$

As such, the United States violated both the LaGrands' and Germany's VCCR rights by not notifying the LaGrands of their consular rights and not notifying Germany that its nationals had been arrested. ${ }^{126}$

The effects of the LaGrand Judgment remain unclear, as other consular notification cases wind their way through the U.S. legal system. ${ }^{127}$ As noted, prior to the ICJ Judgment, the majority of U.S. courts found that the VCCR creates no individual rights. LaGrand has created problems for many courts because it raises fundamental questions such as what weight,

I21. It may be that, as with any other court, states will follow ICJ decisions merely out of respect for the rule of law and not because of an imminent threat of repercussions or retaliation. Mendelson notes that unlike in domestic regimes, fines, sanctions, and imprisonment are not viable options to force international compliance. Mendelson, supra note 117 , at $40-41$.

122. These avenues range from a country's making official statements sounding its displeasure to working to slash the court's budget or jurisdiction. Unhappy governments can apply these tactics domestically or internationally.

123. This claim had been successfully upheld in numerous previous U.S. court decisions. See United States v. Li, 206 F.3d 56,60 (Ist Cir. 2000) (holding "treaties do not generally create rights that are privately enforceable in the federal courts"); see also United States v. Jimenez-Nava, 243 F.3d 192, 195 (5th Cir. 2001); Kasi v. Commonwealth, 508 S.E.2d 57, 64 (Va. 1998). But see State v. Issa, 752 N.E.2d 904, 914-15 (Ohio 2001) (assuming, without deciding, that the Vienna Convention confers individual rights two months after the ICJ's LaGrand Judgment).

124. LaGrand Judgment, 2001 I.C.J. 466, 494 (June 27).

125. Id. at 492 .

126. Id. at 494 .

127. In a handful of cases, the Judgment may have come only shortly before courts handed down related decisions, preventing the Judgment from weighing heavily on the courts' decisions. See United States v. Minjares-Alvarez, 264 F.3d 980, 986 (10th Cir. 2001) (decided one month after LaGrand and stating, "It remains an open question whether the Vienna Convention gives rise to any individually enforceable rights"); Issa, 752 N.E.2d at 914-15. 
if any, a decision of an international tribunal has on domestic legal systems and whether the decision has any precedential value. It was, in fact, these questions that the Suprcme Court had sought to resolve by granting certiorari in Medellin ${ }^{128}$ and again in Sanchez-Llamas and Bustillo. ${ }^{129}$ One study found that "in the six months since the [LaGrand] ruling, seventeen of twenty reported U.S. court decisions on consular rights do not even mention the [ICJ] [J]udgment. None rely [sic] on it. Worse, several contradict it, with no indication that they are even aware of doing so."130

Two cases decided after LaGrand explicitly declined to decide whether the VCCR conveys individual rights. ${ }^{131}$ Two other cases decided that the VCCR does not convey individual rights, squarely contradicting LaGrand..$^{132}$ In Commonwealth v. Diemer, a Massachusetts appeals court noted that "[m]ost courts which have addressed the issue post LaGrand have given the decision little deference." 133 The most likely explanation is that many U.S. courts following LaGrand are unsure whether an ICJ holding is of greater, equal, or lesser weight than dicta from the U.S. Supreme Court. This confusion arises because of the Supreme Court's dicta in Breard, stating the Vienna Convention "arguably confers on an individual the right to consular assistance following arrest."134 The ambiguity created by this single phrase may well be the reason that lower courts have avoided the issue pending further Supreme Court guidance. ${ }^{135}$ It was perhaps with an eye toward finally resolving this conflict that the Supreme Court recently granted certiorari in Sanchez-Llamas and Bustillo. ${ }^{136}$

\section{c. The Applicability of the Procedural Default Rule}

The ICJ next addressed the procedural default rule, under which a defendant loses the opportunity to claim a violation of his consular rights on appeal if he failed to raise the matter in state court-a rule that effectively

\footnotetext{
128. See Questions Presented, Medellin v. Dretke (Medellin II), supra note 6.

129. See Questions Presented, Sanchez-Llamas v. Oregon, supra note 10.

130. Douglass W. Cassel, Jr., Ignoring the World Court, ChI. Dally L. Bull., Jan. 10, 2002, at 6.

131. Commonwealth v. Diemer, 785 N.E.2d 1237, 1244 (Mass. App. Ct. 2003) ("declining to provide a definitive answer to the question" after an extensive review of LaGrand and other cases dealing with the issue); see also Cauthern v. State, 145 S.W.3d 571, 627 (Tenn. Crim. App. 2004) (stating that " $[\mathrm{g}] \mathrm{iven}$ the lack of direction from the United States Supreme Court, we take our lead from the general principle that treaties are not presumed to create privately enforeeable rights").

132. State v. Martinez-Rodriguez, 33 P.3d 267, 274 (N.M. 2001) (holding that "the provisions of the VCCR do not create legally enforceable individual rights," without any reference to LaGrand); Bell v. Commonwealth, 563 S.E.2d 695, 706 (Va. 2002) (holding that "we conclude that the ICJ, contrary to Bell's assertion, did not hold that Article 36 of the Vienna Convention creates legally enforceable individual rights that a defendant may assert").
}

133. 785 N.E.2d at 1242 n.8.

134. Breard v. Greene, 523 U.S. 371, 376 (1998) (emphasis added).

135. See, e.g., United States v. Minjares-Alvarez, 264 F.3d 980, 986 (10th Cir. 2001).

136. Questions Presented, Sanchez-Llamas v. Oregon, supra note 10. 
bars most VCCR claims in U.S. courts. ${ }^{137}$ In a tightly-crafted holding, the ICJ noted that U.S. domestic laws did not violate the spirit of the Vienna Convention per se, but that "the procedural default rule had the effect of preventing "full effect [from being] given to the purposes for which the rights accorded under [the VCCR] are intended,' and thus violated paragraph 2 of Article 36." $" 138$ Thus, the United States violated international law "by the circumstances in which the procedural default rule was applied, and not by the rule as such." 139 The ICJ, therefore, ruled on the applicability of the rule in one specific context without interfering with the domestic legal system of a Member State, which it cannot do. ${ }^{140}$

This portion of the court's Judgment may prove to be the thorniest. Politicians dislike the idea of an unelected international body ruling on the legality of any State's internal system of laws. ${ }^{141}$ To them, the ICJ can only adjudicate whether a Member State has complied with its treaty obligations, and, if not, what possible remedies exist. For the ICJ to reach into U.S. domestic criminal procedure, established by the Congress and finetuned by the judiciary, goes too far.

The scope of the ICJ's procedural default ruling has yet to be fully addressed in U.S. courts. Of the post-LaGrand cases, only a few address the procedural default issue. ${ }^{142}$ Those cases that advance past the individual rights analysis differ in their discussion of the procedural default rule. One court did not even address it, preferring instead to skip directly to possible remedies that exist for a VCCR violation, and finding none. ${ }^{143}$ Others continue to use the procedural default rule as a means to dismiss VCCR claims, in direct conflict with the ICJ's holding. ${ }^{144}$

137. See Breard, 523 U.S. at 375 ("lt is clear that Breard procedurally defaulted his claim"); lbarra v. State, 11 S.W.3d 189, 197 (Tex. Crim. App. 1999).

138. LaGrand Judgment, 2001 1.C.J. 466, 497-98 (June 27).

139. Id. at 513 .

140. The VCCR's terms specifically state that consular rights "shall be exercised in conformity with the laws and regulations of the receiving State," meaning the $\mathrm{ICJ}$ cannot judge the validity of a domestic law. VCCR, supra note 12, at art. 36(2). This rule is "subject to the proviso, however, that the said laws and regulations must enable full effect to be given to" VCCR rights. Id. Thus, the ICJ can judge the validity of the procedural default rule as it applies to VCCR rights internationally without speaking to the validiy of the rule in its domestic context.

141. See, e.g., Virginia Governor Jim Gilmore's statement that delaying Breard's execution "would have the practical effect of transferring responsibility from the courts of the Commonwealth [of Virginia] and the United States to the [1CJ]." Jim Gilmore Statement, supra note 63; see also infra note 249 and accompanying text (noting Texas's view that the President of the United States cannot impose upon Texas the will of a foreign court).

142. This may be due to courts dismissing many claims because of a lack of individually enforceable rights. See infra Part III.B.3.ii.

143. Commonwealth v. Diemer, 785 N.E.2d 1237, 1242 (Mass. App. Ct. 2003) (noting that two issues arise when the state violates a foreigner's VCCR rights: "First, does the treaty confer an individual right that a detainee may pursue? If so, what is the remedy for a violation of that right?').

144. Cauthern v. State, 145 S.W.3d 571, 627 (Tenn. Crim. App. 2004); see also State v. Issa, 752 N.E.2d 904, 915 (Ohio 2001). In Cauthern, the court explained that the defendant's claim was procedurally barred even if Cauthem had an individually enforceable right. Cauthern, 145 S.W.3d at 
Though difficulties arise when drawing conclusions based on a handful of cases, one can guess that courts, and the judges who sit on them, are not that different from politicians. As displeasing as the idea that a foreign court can impose its decisions on the United States may be for politicians, judges may be equally put off by an ICJ Judgment precluding the use of an internal procedural rule. Soon, courts, judges, and politicians will have to address head on the implications of the ICJ's holding that the internal procedural default rule cannot prevent VCCR claims from proceeding in U.S. courts. The Supreme Court may address these concerns in Bustillo. ${ }^{145}$

\section{d. Possible Remedies}

Although the ICJ upheld Germany's claims in the LaGrand Judgment, the court did not adopt the same far-reaching tone in addressing possible remedies for U.S. violations that it used in establishing that the violations had indeed occurred. The ICJ's guarded tone may be the result of leeway created by Germany's requests of the United States in its filings, tailored to leave to the United States the choice of means by which to remedy any future violations. ${ }^{146}$ The court noted that, throughout the proceedings, the United States had "insisted that it 'keenly appreciates the importance of the Vienna Convention's consular notification obligation"' and that the U.S. State Department was "working intensively to improve understanding of and compliance with consular notification and access requirements throughout the United States." 147 Further, the court noted the publication and distribution of a booklet and individual pocket cards for U.S. law enforcement officers. ${ }^{148}$

To the ICJ, this "commitment" met Germany's general demand for an assurance of non-repetition by the United States. ${ }^{149}$ The court agreed to Germany's request for "review and reconsideration" of similar cases in U.S. courts, particularly death penalty cases. ${ }^{150}$ But, it did not agree with

627. The court's holding comes immediatcly after a long discussion of LaGrand and the 1CJ's holding that application of the procedural default rule violated the VCCR. Id. Yet, in spite of this, the Cauthern court procedurally barred Cauthern's claim as against the Tcnnessee cquivalent of AEDPA because the "ground for relief that [Cauthern] pursues could have been, but was not, prcsented for determination in any of the prior proceedings concerning his case." Id. The court did not explain why it avoided applying the ICJ holding. In Issa, the court held that Issa waivcd his VCCR claim "because [he] failed to raise the issue in this trial court." Issa, 752 N.E.2d at 915 . The majority did not acknowledge LaGrand, decided two months earlier.

145. See Questions Presented, Sanchez-Llamas v. Oregon, supra note 10.

146. Specifically, Germany requested that the United States provide assurances that it would not repeat its "unlawful acts" and, in cases involving the death penalty, would provide "effective review of and remedies for criminal convictions" obtained through VCCR violations. LaGrand Judgment, 2001 1.C.J. 466, 508-09.

147. Id at 511 .

148. Id at 511-12.

149. Id. at 516

150. Id. 
Germany's argument that "where it cannot be excluded that the judgment was impaired by the violation of the right to consular notification, appellate proceedings allow for a reversal of the judgment and for either a retrial or a re-sentencing." The court seized upon Germany's proffered remedy and allowed the United States to implement its "review and reconsideration" remedy "by means of its own choosing."151

This rather meek series of remedies may illustrate the ICJ's acknowledgment of political reality. In stating its central holdings, the court ventured further than it had ever gone. The court may have felt that it had consumed all of its political capital and realized that demanding any specific remedy (like an automatic new trial for future violations) would push the United States too far and risk total non-compliance. Though this case did not resemble the I986 Nicaragua Judgment, ${ }^{152}$ in which the United States permanently rejected the ICJ's compulsory jurisdiction, ${ }^{153}$ the court may have been mindful not to push so hard that the United States would reject the court's jurisdiction entirely.

\section{Avena}

Eighteen months after the LaGrand Judgment, Mexico instituted proceedings before the ICJ on behalf of Carlos Avena Guillen and fifty-three other Mexican nationals who had been convicted and sentenced to death in U.S. courts. ${ }^{154}$ The case has become known as Avena, after the first of the fifty-four real defendants in the case.

\section{Preliminary Measures}

When Avena was filed, Mexico's fifty-four nationals were all at various stages in their legal proceedings. Three defendants (César Roberto Fierro Reyna, Roberto Moreno Ramos, and Osvaldo Torres Aguilera) had exhausted all legal options and faced imminent execution, with Reyna scheduled to be executed just one month after Mexico's initial filing. ${ }^{155}$

At Mexico's request, the ICJ issued a Provisional Order to prevent "irreparable prejudice to any rights that may subsequently be adjudged by the Court to belong to Mexico": 156

(a) The United States of America shall take all measures necessary

to ensure that Mr. César Roberto Fierro Reyna, Mr. Roberto

151. Id.

152. Military and Paramilitary Activities (Nicar. v. U.S.), 1986 I.C.J. 14 (June 27).

153. See Letter from George P. Schultz, U.S. Sec'y of State, to Dr. Javier Perez de Cuellar, U.N. Sec'y-Gen. (Oct. 7, 1985), in 24 1.L.M. 1742 (1985).

154. Request for the 1ndication of Provisional Measures (Avena Order), Avena Case (Mex. v.

U.S.) 2004 I.C.J 128 (Mar. 31), available at 2003 WL 256903, \ 11 [hereafter Avena Order].

155. Id.

156. Id. ๆ 55 . 
Moreno Ramos and Mr. Osvaldo Torres Aguilera are not executed pending final judgment in these proceedings;

(b) The Government of the United States of America shall inform the Court of all measures taken in implementation of this Order. ${ }^{157}$

The ICJ adopted stricter language in this PMO than its previous Orders in Breard and LaGrand. ${ }^{158}$ Where the court had previously used more conciliatory language-_" "[t]he United States of America should take all measures at its disposal"159 - the court now ordered that "[t]he United States of America shall take all measures necessary." 160 None of the three individuals named in the PMO were executed while the United States and Mexico argued the merits of the claim before the ICJ.

\section{Final Judgment}

On March 31, 2004, the ICJ rendered its final judgment in Avena. ${ }^{161}$ The fifty-two Avena defendants' cases presented various factual situations leading to potential VCCR violations and different procedural postures. ${ }^{162}$ In twenty-nine cases, Mexican consuls learned of the detention of their nationals only after a death sentence had been imposed. ${ }^{163}$ Of the remaining twenty-three cases, Mexico learned of the violation when it was too late to affect the trial (five cases), when the defendant had already made incriminating statements (fifteen cases), or after "considerable delay" (three cases). ${ }^{164}$ Of the fifty-two defendants, twenty-four were directly appealing their convictions, twenty-fivc more had exhausted direct appeals but could still avail themselves of federal habeas corpus petitions, and three (Reyna, Ramos, and Torres) had exhausted all judicial appeals. ${ }^{165}$

\section{a. "Without Delay" and the Adoption of Miranda-Like Advisories}

Addressing the merits of Mexico's claims under Article 36(1)(b), the ICJ held that a State must inform a foreign defendant's consulate "without delay" when it realizes or has grounds to believe that the defendant is

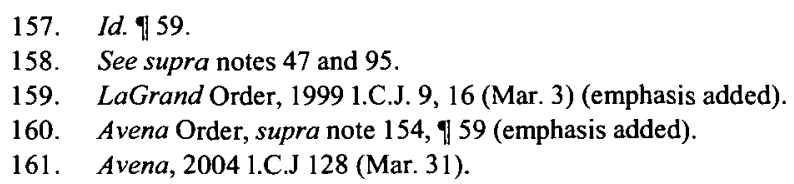

162. By the time the court decided the case, the list of fifty-four claimants had been narrowed to fifty-two because one claimant was a dual Mexican/American citizen and the other claimant had been informed of his consular rights. Id. I 7. Two days after Mexico filed its application with the 1CJ, then Governor Gcorge Ryan of lllinois exercised his power of clemency and commuted all death sentences in his state. Jodi Wilgoren, Citing Issue of Fairness, Governor Clears Out Death Row in Illinois, N.Y. Times, Jan. 12, 2003, at 1. This included the sentences of three Avena defendants. Avena, 2004 1.C.J 128,721 . Mexico did not change its petition to remove those claimants, and the $1 \mathrm{CJ}$ kept the three individuals within the scope of its Judgment.

$$
\begin{aligned}
& \text { 163. Id. } \ 19 . \\
& \text { 164. Id. } \\
& \text { 165. Id. } 120 .
\end{aligned}
$$


probably a foreign national. ${ }^{166}$ However, the court noted that "[p]recisely when this may occur will vary with circumstances," 167 and that, therefore, " "without delay' is not necessarily to be interpreted as 'immediately' upon arrest." 168 The court examined some of the Avena claimants' cases to help identify circumstances that led to violations under the VCCR. ${ }^{169}$ The United States had failed to meet the "without delay" requirement in fiftyone of the fifty-two cases before it. ${ }^{170}$ Indeed, most often, information on VCCR rights "was given either not at all or at periods very significantly removed from the time of arrest." 171 Thus, based on the Avena court's findings, one may deduce that States can violate the "without delay" requirement as quickly as forty hours after the arrest of a foreign national. ${ }^{172}$

Because the "without delay" problem can prove tricky and each decision will turn on the specific facts of the case, the ICJ suggested the adoption of a Miranda-like advisory for law enforcement officers to read to all suspects upon arrest. ${ }^{173}$ The court reasoned that "were each individual to be told at that time that, should he be a foreign national, he is entitled to ask for his consular post to be contacted, compliance with [the VCCR's 'without delay'] requirement... would be greatly enhanced."174 Responding to the U.S. government's concern that its multicultural society makes determination of citizenship more difficult, the court noted, "the large numbers of foreign nationals living in the United States ... suggest that it would be desirable for enquiry routinely to be made of the individual as to his nationality upon his detention, so that the obligations of the Vienna Convention may be complied with." 175

The ICJ is not alone in calling for the adoption of Miranda-like advisories for all arrestees. ${ }^{176}$ The idea has been addressed both in law review articles ${ }^{177}$ and by a state legislature. ${ }^{178}$ It remains unclear how U.S. federal authorities will respond to the ICJ's suggested preventative course.

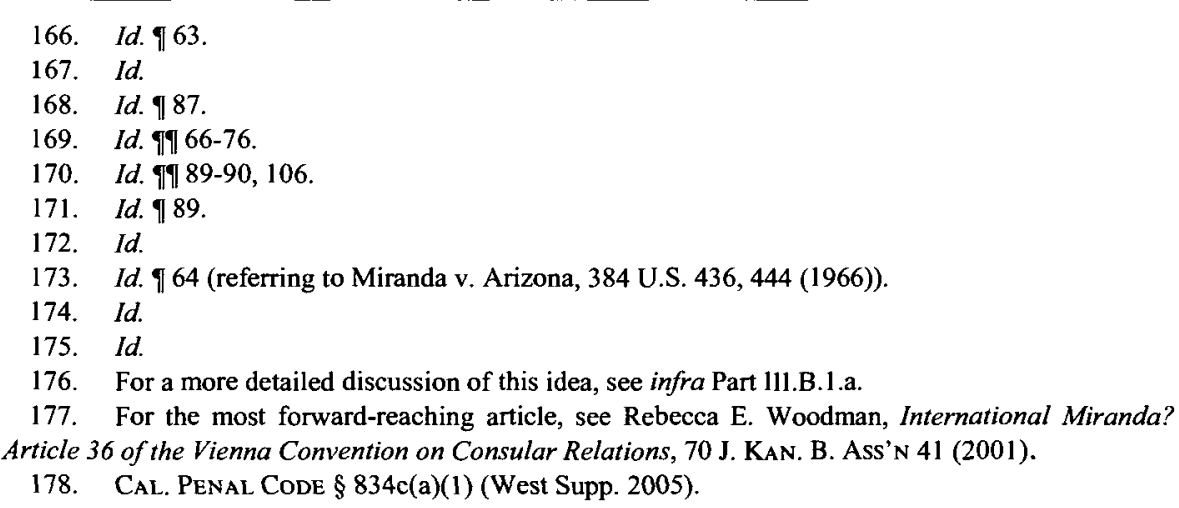




\section{b. Procedural Default}

The court next addressed Mexico's claim that domestic U.S. laws, such as the procedural default rule, prevented "meaningful and effective review and reconsideration" of sentences imposed after VCCR violations. ${ }^{179}$ Affirming its position in LaGrand, the ICJ observed that the United States had not modified the procedural default rule "to prevent its application in cases where it has been the failure of the United States itself to inform that may have precluded counsel from being in a position to have raised the question of a violation of the Vienna Convention in the initial trial." ${ }^{80}$ The court thus concluded that "the procedural default rule may continue to prevent courts from attaching legal significance to the fact, inter alia, that the violation of the [VCCR] rights ... prevented Mexico, in a timely fashion, from retaining private counsel for certain nationals and otherwise assisting in their defence." 181

Accepting that the United States had yet to change the procedural default rule, the court examined the rule's implications for the fifty-two claimants. In the forty-nine cases still working their way through the criminal justice system, it was too early for the ICJ to determine whether violations occurred because "all possibility is not yet excluded of 'review and reconsideration' of conviction and sentence."182 But in the three cases for which a Provisional Order was granted because all appeals had been exhausted, the court found that the United States had breached its VCCR obligations. ${ }^{183}$

The ICJ's brief discussion of the procedural default rule hints at its continued concern that the United States will not fully comply with the VCCR unless the United States modifies or eliminates the rule. This is significant for two reasons. First, the ICJ's Judgments appear to grow stronger and bolder with each successive decision. The ICJ, which cannot work on a precedential basis like domestic common law courts, nonetheless affirmed one of its core holdings from LaGrand. The court quoted its previous holding on the procedural default rule, reiterating that " $[t]$ his statement of the Court seems equally valid in relation to the present case." ${ }^{84}$ Second, Avena may also signal the court's unwillingness to engage U.S. claims on the issue unless the United States removes the procedural default rule as a barrier to effective review and reconsideration. Anything less than this, the court may be signaling, is unacceptable.

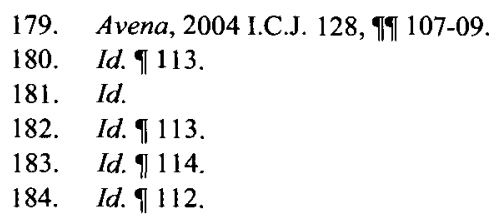




\section{c. Remedies}

As it did in LaGrand, the ICJ issued strong, clear statements in its holdings in Avena, but toned down its rhetoric in discussing the remedies for U.S. breaches of the VCCR. The court held that the appropriate remedy would be "to permit review and reconsideration of these nationals' cases by the United States courts." "185 The ICJ's hesitance to accept U.S. assertions that executive clemency can be part of the review and reconsideration may explain the addition of the word "courts" to the Judgment. ${ }^{186}$

Except for mandating domestic court review, the ICJ once again left it to the United States to determine how best to effectuate the call for "review and reconsideration" of the convictions and sentences in light of the court's holding. ${ }^{187}$ The court did sound more authoritative in its abdication of power than it did in LaGrand, noting "this freedom in the choice of means for such review and reconsideration is not without qualification: ... [it] has to be carried out 'by taking account of the violation of the rights set forth in the Convention." "188

In discussing appropriate remedies, the ICJ also refused to consider Mexico's claim that the exclusionary rule ${ }^{189}$ is an international principle that can be applied to the cases at hand. ${ }^{190}$ The court's unwillingness to engage in that discussion may prove costly for defendants. Even in previous U.S. court cases recognizing a violation of an individual's right under the VCCR, courts have refused to apply the exclusionary rule as a remedy. ${ }^{191}$ Applying the deferential "clearly erroneous" standard of review, these courts have generally held the resultant error insufficiently egregious to warrant exclusion. ${ }^{192}$ Courts generally look to whether VCCR violations "prejudiced" the proceedings, which they rarely find. ${ }^{193}$ Indeed, the Ortiz court explained:

That [VCCR] violations occurred is a fact, but it is a disembodied

fact. Courts have no authority to enforce the law, including treaties,

185. Id. $\ 121$.

186. Id. ๆ 141-42.

187. Id. 1122.

188. Id. 1131 .

189. See Oregon v. Elstad, 470 U.S. 298, 306-07 (1985). "The Fifth Amendment prohibits use by the prosecution in its case in chief only of compelled testimony. Failure to administer Miranda warnings creates a presumption of compulsion. Consequently, unwamed statements that are otherwise voluntary within the meaning of the Fifth Amendment must nevertheless be excluded from evidence under Miranda. Thus, in the individual case, Miranda's preventive medicine provides a remedy even to the defendant who has suffered no identifiable constitutional harm." Id. (emphasis in original). VCCR violations parallel Miranda violations by creating a "presumption of compulsion," and would be subject to the same excusionary nule remedy.

190. Avena, 2004 1.C.J. 128, ๆ 127.

191. See, e.g., United States v. Minjares-Alvarez, 264 F.3d 980, 987 (10th Cir. 2001); Commonwealth v. Diemer, 785 N.E.2d 1237 (Mass. App. Ct. 2003).

192. See, e.g., Minjares-Alvarez, 264 F.3d at 988.

193. See, e.g., United States v. Ortiz, 315 F.3d 873, 887 (8th Cir. 2003). 
in a vacuum, so to speak. Our job is simply to decide the cases that come before us, and to do so in a way that is just.... That the [VCCR] was violated in these cases is not something to be proud of.... [P]rior cases demonstrate that this nation's overall compliance record leaves a good deal to be desircd. This fact, however, does not automatically translate into relief for particular defendants in particular cases. ${ }^{194}$

Even if a domestic court recognizes a VCCR violation, Avena claimants would likely win a hollow victory without access to the exclusionary rule's remedy. They will continue to languish in prison, even though everyone agrees their rights have been violated and courts lament the fact that they have "no authority to enforce the law."195

\section{Medellin}

Following Avena, Jose Medellin, one of the fifty-one real defendants held to have individually enforceable rights in the case, filed a petition for a writ of habeas corpus in federal district court to review his conviction for capital murder and subsequent death sentence. ${ }^{196}$

\section{Background}

On June 24, 1993, Medellin, a Mexican citizen, raped and killed two teenage girls in Texas after a gang initiation. ${ }^{197}$ He returned to his family's home sometime later and boasted that he and his friends "'had fun' and that their exploits would be seen on the television news." 198 Medellin explained that he helped kill at least one of the girls with a shoelace he took off of his shoe, and that when he encountered difficulty, "he put his foot on her throat because she would not die." 199

Medellin's conviction and death sentence were affirmed on direct appeal. ${ }^{200}$ State and federal appellate courts denied subsequent appeals, including the denial of a certificate of appealability (COA) needed for further review in federal courts. ${ }^{201}$ Medellin argued various claims in his federal appeals, including, for the first time, the violation of his consular rights. ${ }^{202}$ Texas conceded that Medellin "was not notified of his right to contact the Mexican consul.".203 Nonetheless, the Fifth Circuit held that Medellin

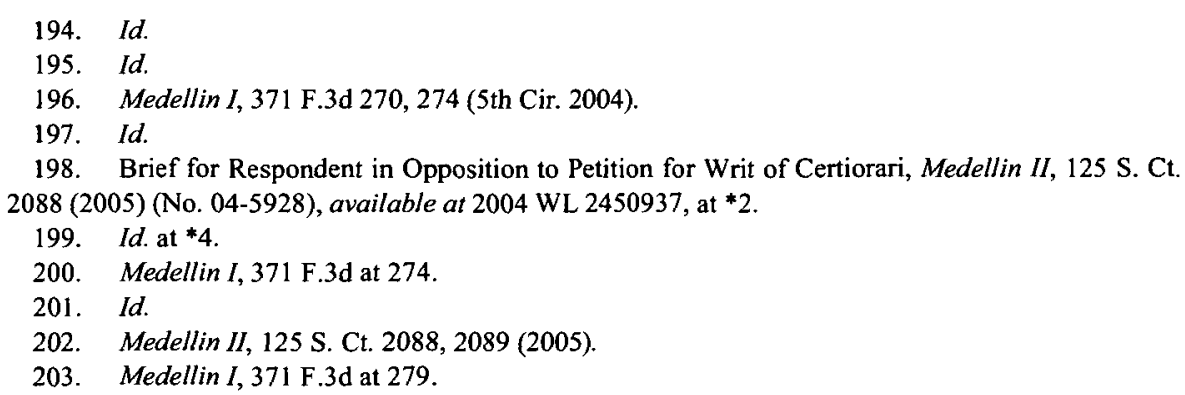


procedurally defaulted on his claim and, even if he did not, the VCCR did not confer an individual right for Medellin to bring suit for violation of his rights. ${ }^{204}$ Although it recognized that the ICJ rejected these two holdings in LaGrand and Avena, the court held that Supreme Court precedent bound its decision: "[W]e may not disregard the Supreme Court's clear holding that ordinary procedural default rules ean bar Vienna Convention claims ... . [O]nly the Supreme Court may overrule a Supreme Court decision." ${ }^{205}$ Medellin thus petitioned the Supreme Court for a writ of certiorari to address that issue.

\section{Last-Minute Executive Maneuvering}

On the last day for filing the government's briefs in Medellin, the Solicitor General filed an amicus brief that argued: 1) the Supreme Court should not address the merits of the case because of a technical requirement involving AEDPA, and 2) even if the Court did reach the merits, it should defer to the executive branch, which alone could decide whether the VCCR conveyed individual rights upon defendants. ${ }^{206}$ The brief argued that "[i]t is for the President, not the courts, to determine whether the United States should comply with the [Avena] decision, and, if so, how."207 The Supreme Court disagreed and granted Medellin's petition for writ of certiorari-ostensibly to review those very issues. ${ }^{208}$

After the Court's decision to grant certiorari and one month before oral arguments, President Bush sent a memorandum to Attorney General Gonzalez declaring that the ICJ had jurisdiction over the United States as a party to the VCCR, and, as such, the United States was bound to abide by the ICJ Judgment. ${ }^{209}$ The President further declared:

1 have determined, pursuant to the authority vested in me as President by the Constitution and the laws of the United States of America, that the United States will discharge its international obligations under the decision of the [1CJ] in [Avena], by having State courts give effect to the decision in accordance with general principles of comity in cases filed by the 51 Mexican nationals addressed in that decision. ${ }^{210}$

204. Id.

205. Id. at 280 .

206. Brief for the United States as Amicus Curiae Supporting Respondent at 10-12, Medellin II, 125 S. Ct. 2088 (2005) (No. 04-5928) (on file with author), available at http://www.scotusblog.com/ movabletype/archives/medellin.sg.brief.pdf.

207. Id. at 11 (explaining that as "the nation's representative in foreign affairs," it is within the executive's sole discretion to determine U.S. complianee, if any, with the Avena Judgment).

208. Medellin I, 371 F.3d 270.

209. Memorandum from George W. Bush to the Attorney General, supra note 8.

210. Id. 
One week later, President Bush withdrew from the Optional Protocol. ${ }^{211}$ As a result, the ICJ no longer retains jurisdiction to hear future VCCR claims against the United States. But the action did not free the United States from obligations incurred from past and present suits. Thus, the United States must continue to comply with both the LaGrand and Avena judgments. By withdrawing from the Optional Protocol, however, President Bush ensured that other states could not bring the United States before the ICJ for further rounds of adjudication concerning VCCR violations. With more than sixty forcign nationals from thirty countries awaiting execution in the United States, many States and individuals had standing to do so. ${ }^{212}$

\section{Supreme Court Decision}

In a per curiam, 5-4 decision, the Court dismissed certiorari in Medellin as improvidently granted. ${ }^{213}$ Recognizing the Bush memo's direction for state-level review, the Medellin majority found that this newlyopened avenue "may provide Medellin with the very reconsideration of his Vienna Convention Claim" that he had sought from the Court. ${ }^{214}$ The Court also noted that the merits briefings highlighted "a number of hurdles"215 or "thrcshold issues" Medellin must overcome before gaining federal relief. ${ }^{216}$ As a result of these hurdles and the lower court's ability to review the case, the Court found "it would be unwise to reach and resolve the multiple hindrances to dispositive answers to the questions here presented," and therefore dismissed the case..$^{217}$

Concurring, Justice Ginsburg stated a preference for granting Medellin's petition to stay the proceedings pending his pursuit of further remedies in Texas courts, but that this "most conservative" remedy had not garnered a majority. ${ }^{218}$ Justice Ginsburg also noted the Court's division

211. Letter from Condoleeza Rice to Kofi Annan, supra note 7.

212. WARREN, supra note 25 .

213. Medellin II, 125 S. Ct. 2088, 2089 (2005).

214. Id.

215. Id.

216. Id. at 2090-92. These "threshold issues" include: 1) whether Reed v. Farley, 512 U.S. 339 (1994) (holding that a violation of a federal statutory right (like the VCCR) may not be cognizable in a federal habeas proceeding unless it meets the "fundamental defect" test), bars his treaty claim; 2) whether Medellin can overcome a highly deferential standard of review regarding all trial court findings of facts; 3) how Avena bears on its "new rule" jurisprudence, under which a federal habeas petitioner cannot sue to enforce a new rule of law; 4) whether Medellin could obtain a COA by demonstrating that his allcgation of a treaty violation meets the standard for granting a COA; and 5) whcther Medellin could show that he had exhausted his remedies in state court prior to seeking federal relief. $I d$. An analysis of Medellin's likelihood of success in overcoming these hurdles is beyond the scope of this Comment.

217. Id. at 2092 .

218. Id. at 2093 (Ginsburg, J., concurring). Justices Souter, Stevens, and Breyer agreed with this preferred course, but because granting Medellin's petition to stay the proceedings did not garner a majority, chose instead to dissent. Id. at 2106-08 (Souter, J., dissenting; Breyer and Stevens, JJ., dissenting). 
between two responses: 1) to remand the case to the federal courts, as the dissent argued, or 2) to dismiss the writ entirely, leaving "nothing pending" at the Court, as the majority held. ${ }^{219}$ She warned, however, that "it will be this Court's responsibility, at the proper time and if need be, to provide the ultimate answers."220 Thus, while siding with the four other justices who would wash their hands of the matter entirely, Justice Ginsburg's concurrence might signal her belief that the issue would return to the Court for ultimate resolution sooner, rather than latcr.

The primary dissent, penned by Justice O'Connor, called the majority's decision to dismiss certiorari an action based on "speculation," and echoed Justice Ginsburg's warning: "It seems to me unsound to avoid questions of national importance when they are bound to recur."221 Disapproving of the majority's listing of "hurdles" as a basis for dismissal, Justice $\mathrm{O}^{\prime}$ Connor noted the issue before the Court was whether Medellin's claims satisfied the COA standard: "It seems odd to me to leave [the issues] undecided and yet to rely on them as reason to avoid the weighty questions that are undeniably properly before us .... [O]ur modest task is to decide only whether Medellin has presented claims worthy of a COA, and the majority points to issues outside the scope of that inquiry."222 Analyzing the COA claim, Justice O'Connor found the Fifth Circuit "should have granted a COA" to consider whether it was bound by Avena, but did not render an ultimate opinion on the weight that U.S. courts should give to Avena, if any. ${ }^{223}$

Justices Breyer and Stevens agreed with O'Connor that vacating and remanding the lower court opinion was the appropriate measure. They found the Fifth Circuit erred in not finding that Medellin's legal arguments were substantial enough to merit a COA. ${ }^{224}$ Thus, vacating and remanding "would remove from the books an erroneous legal determination."225

\section{III}

\section{AddRessing Past and Future VCCR Violations}

In its opening brief to the ICJ in Avena, the Mexican government suggested that VCCR violations are not a thing of the past and continue today-after the United States apologized to Paraguay and after LaGrand. ${ }^{226}$

\footnotetext{
219. Id. at 2093 (Ginsburg, J., concurring).

220. Id. at 2095.

221. Id. at 2095-96 (O'Connor, J., dissenting).

222. Id. at 2100 (emphasis in original).

223. Id. at 2102 .

224. Id. at 2107 (Breyer and Stevens, JJ., dissenting).

225. Id.

226. See Mexican Memorial, 20 June 2003, at http://www.icj-cij.org/icjwww/idocket/imus/ imuspleadings/imus_ipleadings_20030620_memorial_03.pdf, at para. 161 (noting 102 cases of VCCR violations among Mexicans nationals found in an internal investigation conducted after Breard and LaGrand).
} 
Indeed, President Bush's decision to withdraw from the Optional Protocol has been seen as an action taken to avoid such future cases. ${ }^{227}$ Thus, regardless of how the individual case in Medellin eventually turns out, it is necessary to examine remedies available to address past VCCR violations as well as prophylactic measures to prevent future violations. Because the Supreme Court has shown that it neither needs nor wants to be the sole governmental organ that engages the Avena and LaGrand Judgments, other state and federal institutions will play pivotal roles in the upcoming months.

\section{A. Remedies for Past VCCR Violations}

\section{Executive Actions}

The executive branch may play the most important role in remedying VCCR violations in the near future. Though state governors were originally thought to exert the most influence in determining the fate of foreign nationals whose VCCR rights were violated, ${ }^{228}$ President Bush has now shown that the federal executive may also play a substantial role.

\section{a. State Governors}

The ICJ Judgments leave to the three branches of the U.S. government how best to determine and implement the remedies for a VCCR violation. ${ }^{229}$ A majority of states where foreign nationals await death are "tough on crime" states that rarely grant convicted murderers clemency. One report observes that apart from the mass clemencies granted by Illinois Governor Ryan in $2003,{ }^{230}$ governors of the thirty-eight states with death penalties have commuted only twenty-seven death sentences in the last thirteen years. ${ }^{231}$ Given the "tough on crime" stance of many politicians and their seeming refusal to be swayed by an international court's judgment, the ICJ justifiably expressed misgivings about the clemency process in Avena. ${ }^{232}$ Thus, going one step further than it did in LaGrand, the ICJ

227. Charles Lane, High Court Rejects Case of Mexican Death Row Inmate, WASH. PosT, May 24, 2005 , at A6.

228. This is because Presidents Clinton and George W. Bush and their advisors, including the Solicitor General and the Secretary of State, had been lukewarm to VCCR claims, showing little interest in intervening in the matters. See Letter from Madcleine K. Albright to James S. Gilmorc 1Il, supra note 51; Letter from Seth P. Waxman to William Suter, supra note 99.

229. See LaGrand Judgment, 2001 1.C.J. 466, 516 (June 27); Avena, 2004 I.C.J. 128, I 205 (Mar. 31).

230. Wilgoren, supra note 162.

231. Bob Egelko, Governor Sets High Bar for Clemency; Beardslee Case Indicates Standard Will Be Legal Insanity, S.F. Chron., Jan. 21, 2005, at B3.

232. The refusal of clemency in Breard and LaGrand, where it was the sole remedy remaining for the defendants, support this hesitation. See supra Parts II.A and II.B. 
expressly found that clemency review alone would not suffice to meet the "review and reconsideration" requirement of its Judgment. ${ }^{233}$

To date, only one Avena defendant has received clemency via the executive branch. Just six weeks after the ICJ Judgment in Avena, Oklahoma Governor Brad Henry commuted the sentence of Osbaldo Torres, an Avena defendant who had exhausted all judicial avenues and awaited the scheduling of an execution date. ${ }^{234}$ The Governor noted: "My heart goes out to the [victims' families]. This was [sic] difficult decision, but I believe clemency is warranted by a number of issues involved in this case." ${ }^{235}$ Central issues included the Avena ruling, taking "into account the fact that the U.S. signed the 1963 Vienna Convention and is part of that treaty," and that the U.S. State Department urged the Governor to give "careful consideration" to the ICJ ruling. ${ }^{236}$ Though the text of the State Department letter was not made available, it was most likely similar to letters to Governors Gilmore and Hull urging review of ICJ rulings. ${ }^{237}$

The 1CJ may have been surprised to learn that one defendant received clemency specifically because of Avena, reducing his sentence to life imprisonment without parole. But, one governor granting clemency to one defendant cannot be taken as a sign that the clemency process will work or be consistent in the long run. The execution of Hung Thanh Le, a Vietnamese foreign national on Oklahoma's death row whose clemency request Governor Henry denied just one month prior to the Governor's grant of clemency to Torres, provides an unfortunate example of the clemency process's inconsistency. ${ }^{238}$ Though Governor Henry granted a onemonth stay of Le's execution in response to a formal request by Vietnam, the Governor denied clemency, and Le was executed on March 23, $2005 .{ }^{239}$

How governors will decide the fate of the fifty remaining Avena defendants and other foreign nationals whose VCCR rights have been violated remains a mystery. Will we see more successes like Osbaldo Torres, or further disappointments like Hung Thanh Le? History and the political climate appear to favor the latter.

233. Avena, 2004 I.C.J I28, 9 I I I I-42 (Mar. 3I).

234. Press Release, Office of Governor Brad Henry, Gov. Henry Grants Clemency to Death Row Inmate Torres (May 13, 2004), available at http://www.governor.state.ok.us/ display_article.php?article_id=301\&article_type=1. Governor Henry's statement references "Osbaldo Torres" whereas the ICJ opinion spells the name "Osvaldo." The individual in question, however, is the same person.

235. Id.

236. Id.

237. See, e.g., Letter from Madeleine K. Albright to James S. Gilmore III, supra note 5I.

238. Press Release, Office of Governor Brad Henry, Gov. Henry Grants Stay, Sets New Execution Date (Feb. 27, 2004), available at http://www.govemor.state.ok.us/ display_article.php?article_id=240\&article_type $=1$.

239. See Mark Warren, Human Rights Research, Confirmed Foreign Nationals EXECUTED SINCE 1976 (2004), available at http://www.deathpenaltyinfo.org/article.php? scid $=3$ I \&did $=582$ \# executed. 


\section{b. The President and Federal Agencies}

President Bush's motives in declaring his desire to enforce Avena is unclear. The President's directive may have tried to stop the Supreme Court from deciding Medellin, either by declaring the issue moot or by declaring himself the sole arbiter of Avena's enforceability. Though the directive complies with the ICJ's call for "review and reconsideration," "its narrowness is indicative of the Executive's intent to comply only as a matter of grace in this one instance, but not to follow what the ICJ has determined to be a requirement under the Vienna Convention."240

The executive branch, under both Presidents George W. Bush and Clinton, has not been very receptive to the idea that VCCR claims can be enforced in the United States. Thus, President Bush's directive contradicted the federal executive's previous willingness to defer such decisions to states. Indeed, when asked by the ICJ to "take all measures at its disposal" ${ }^{\prime 241}$ to ensure that Breard and LaGrand were not executed, the federal executive branch claimed that it had no power to intervene aside from writing letters to argue that a state should not execute a foreign national. ${ }^{242}$ Later, when asked to "take all measures necessary" 243 to ensure that the three Avena defendants were not executed, the U.S. State Department did not respond at all to the ICJ's Provisional Order to indicate one way or the other the United States' willingness to comply with the Order ${ }^{244}$ The three defendants were not executed pending the ICJ's final Judgment because local and state prosecutors, not federal officials, agreed to abide by the Provisional Order in a deal with Mexico's attorneys. ${ }^{245}$

But Bush's unilateral decision to leave to the states the qucstion of how to comply with Avena does not mean that, magically, they will comply. The question now arises whether the federal government can compel state courts and governors to comply with its interpretation of an international court's judgment. Bush's directive creates tension in the balance between state and federal powers and opens a new front in the battle over the extent of the federalism and separation of powcrs doctrines.

State courts may be more likely to comply with a United States Supreme Court ruling that states must give effective "review and reconsideration" to the fifty-one Avena defendants' claims, perhaps

240. Nicole L. Aeschleman, Comment, The Vienna Convention on Consular Relations: Quo Vadis, America?, 45 SANTA Clara L. Rev. 937, 971 (2005).

241. Breard Order, 1998 1.C.J. at 258; LaGrand Order, 1999 I.C.J. at 16.

242. See Letter from Madeleine K. Albright to James S. Gilmore III, supra note 51.

243. Avena Order, supra note 154, ๆ 59.

244. Sandra Babcock, Address at Boalt Hall School of Law (Oct. 12, 2005). Babcock represented Mexico before the ICJ in the Avena proceedings.

245. Id. 
because the Supreme Court can review the lower court's dccision. ${ }^{246}$ But, the thornier question arises of whether a branch of the federal government can compel a state's political branches to act. As Bush's order may demand that states act in ways they may not otherwise have acted, the situation grows increasingly complicated.

States normally retain control of their criminal justice systems. But the federal government's exclusive purview in international matters can interject it into a state's traditional domain. ${ }^{247}$ Thus, the U.S. Supreme Court may review state court decisions seeking to provide "review and reconsideration" to VCCR claims. Further, requiring a Miranda-like advisory for all state law enforcement officials as the ICJ suggests, whether issued by the fedcral judiciary or political branches, affects not only state courts but state and local police practices.

These overlapping considerations led the Texas Attorney General's spokesman, when told of the Bush directive, to say: "We respectfully believe thc executive determination exceeds the constitutional bounds for federal authority." 248 Texas subsequently filed a brief arguing that its formor governor was trying to impose on the sovereign state of Texas not only his will but that of a foreign court. ${ }^{249}$ Rather than acknowledge Medellin's new right to have a hearing in a Texas court, Texas is "going to fight" thc Bush directive. ${ }^{250}$

Even assuming that President Bush and future Presidents are serious about compelling the states to comply, thc impact of Bush's directive remains far from certain, even in the short run. If Texas ignores the memorandum as it has signaled it may do, the Medellin case may return rather quickly to the Supreme Court for resolution of the issue. But the path for the other forty-ninc defendants ${ }^{251}$ seems less clear. Without an immediate lifeline to the Court, the defendants may end up in limbo if the governors

246. See Louis Klarevas \& Howard S. Schiffman, The Supreme Court Considers the Rights of Foreign Citizens Arrested in the United States: Examining a Case that Could Dramatically Affect the Way Americans Are Treated When Arrested Abroad, FindLaw, Mar. 21, 2005, http://writ.corporate.findlaw.com/commentary/20050321_schiffman.html (noting that "it is possible that without express direction form the high court, state officials may even fail to comply properly with President Bush's current request for 'review and reconsideration' of the Avena cases").

247. See Zschernig v. Miller, 389 U.S. 429 (1968) (holding that even probate matters, traditionally reserved to states, can violate the federal government's foreign relations objectives); Am. Ins. Ass'n v. Garamendi, 123 S. Ct. 2374 (2003) (holding that a state statute requiring automobile insurance companies to disclose Holocaust-era policies violated the federal government's handling of foreign affairs).

248. Klarevas \& Schiffman, stupra note 246.

249. Lane, supra note 227.

250. Posting of Julian $\mathrm{Ku}$ to Opinio Juris, Medellin: So Who Won?, available at http://lawofnations.blogspot.com/2005/05/medellin-so-who-won.html (May 23, 2005, 10:56 EST).

251. The original fifty-one defendants included Medellin and Torres. Torres's clemency grant and penalty reduction effectively removes his case from future VCCR claim adjudication. 
of their states of scheduled execution refuse to address Bush's authority to force the matter.

\section{Judicial Actions}

Because enacting legislation takes time and the executive's aversion to act effectively may hinder justice, ${ }^{252}$ the judiciary may play an important role in carrying out the "review and reconsideration" required by Avena. But two post-LaGrand cases in U.S. courts, Valdez and Diemer, highlight the subjective and arbitrary nature of even the judicial review process, and show why the ICJ should have required tightened scrutiny over the United States' chosen remedies.

\section{a. Valdez}

If the executive and legislative branches fail to provide effective remedies, appellate courts may wish to remand VCCR cases for resentencing. The Oklahoma Court of Criminal Appeals did just that in Valdez $v$. State by "exercis[ing] its power to grant relief when an error complained of [such as a violation of the Vienna Convention] has resulted in a miscarriage of justice." ${ }^{253}$ Gerardo Valdez was a Mexican national sentenced to death for first-degree murder. ${ }^{254}$ The Mexican government was not notified of his arrest, and only became aware of his case when a relative contacted the Mexican consulate in Texas. ${ }^{255}$ Consular officials investigated Valdez's background in Mexico and learned he "suffer[ed] from severe organic brain damage; was born into extreme poverty; received limited education, and grew up in a family plagued by alcohol abuse and instability ... [ [H]e [also] experienced head injuries in his youth which greatly contributed to and altered his behavior."256

Because of this new information, the Oklahoma Pardon and Parole Board recommended the governor commute Valdez's death sentence to life in prison without the possibility of parole. ${ }^{257}$ The U.S. government also recommended leniency. In a letter to Oklahoma Governor Frank Keating, the legal advisor to the State Department wrote:

I respectfully request that, as part of your consideration of the Valdez case, you specifically consider whether the VCCR violation

252. This is evidenced by statements from the U.S. Secretary of State, the Solicitor General, and Governors Gilmore, Hull, and even Keating in this case. See Letter from Madeleine K. Albright to James S. Gilmore 111, supra note 51; Letter from Seth P. Waxman to William Suter, supra note 99; Jim Gilmore Statement, supra note 63; Jane Dee Hull Statement, supra note 106; Letter from William H. Taft IV, Legal Adviser, U.S. Dep't of State, to Frank Keating, Gov. of Okla., in Department of State Letter to U.S. Court After LaGrand Decision, 96 AM. J. INT'L. L. 461 (2002).

253. Valdez v. State, 46 P.3d 703, 710 (Okla. Crim. App. 2002).

254. Id. at 704 .

255. Id. at 705 .

256. Id. at 706 (footnote omitted).

257. Id. 
had any prejudicial effect on either Mr. Valdez's conviction or his sentence. In assessing whether the violation had a prejudicial effect, you may wish to consider the extent to which the violation may have had a substantial adverse effect on the quality of $\mathrm{Mr}$. Valdez's legal representation at the guilt or sentencing phases, and if so, whether any resulting deficiencies in counsel's performance, when considered in light of the trial record or other available information, substantially undermine your confidence in the correctness of the conviction or sentence. ${ }^{258}$

Governor Keating denied clemency, contrary to this half-hearted appeal of the federal government and the advice of his own Parole Board. ${ }^{259} \mathrm{He}$ explained his decision in a letter to Mexican President Vicente Fox:

Mr. Valdez was afforded all rights under the United States Constitution and the Oklahoma Criminal Code. ...

Taking the decision in LaGrand into account, I have conducted this review and reconsideration of Mr. Valdez's conviction and sentence by taking account of the admitted violation of Article 36 of the Vienna Convention regarding consular notification, as well as the information provided by, among others, representatives of your government.

While it is true that Mr. Valdez was not notified of his right to contact the Mexican Consulate in clear violation of Article 36 of the Vienna Convention on Consular Relations, that violation, while regretful and inexcusable, does not, in and of itself, establish clearly discernible prejudice or that a different conclusion would have bcen reached at trial or on appeal of Mr. Valdez's conviction or sentence. . . . 260

Valdez filed for post-conviction relief based on LaGrand, claiming that "the State of Oklahoma is bound by the law of treaties to the same extent as the United States."261 The Oklahoma court held that the U.S. Supreme Court's Breard decision trumped the ICJ's LaGrand decision: "For this Court to decide the ICJ's ruling overrules a binding decision of the United States Supreme Court and affords a judicial remedy to an individual for a violation of the Convention would interfere with the nation's foreign affairs and run afoul of the U.S. Constitution." ${ }^{262}$ But even though the court did not decide the case based on LaGrand, it ordered a new sentencing hearing because "[i]n hindsight, and so many years

258. Letter from William H. Taft IV to Frank Keating, supra note 252, at 462.

259. Valdez, 46 P.3d at 706.

260. Letter from William H. Taft IV to Frank Keating, supra note 252, at 462-63.

26I. Valdez, 46 P.3d at 708.

262. Id. at 709 . 
following [Valdez's] conviction and direct appeal, it is difficult to assess the effect consular assistance, a thorough background investigation and adequate legal representation would have had."263

Valdez exemplifies the ICJ's call for individual "review and reconsideration." When the executive clemency process fails, as it did in Valdez, appellate courts may grant new sentencing hearings to individually examine what effect violations of consular rights have had on a case.

\section{b. Diemer}

Whereas the Valdez court used its equitable powers to enforce the spirit of LaGrand, the Appeals Court of Massachusetts rigidly refused to apply an equitable remedy for Sven Olaf Diemer. ${ }^{264}$ Diemer, a German national, was convicted of being an accessory after the fact to murder ${ }^{265}$ Nearly a year after the murder, the German consulate informed the Florida Department of State, which had arrested and interrogated Diemer, that his consular rights may have been violated. ${ }^{266}$ The Florida Department of State duly apologized. ${ }^{267}$ The trial court denied Diemer's motion to suppress statements due to the VCCR violations and convicted him. ${ }^{268}$

On appeal, the Massachusetts court disregarded the fact that the ICJ had directly held in LaGrand that the VCCR conveys individually enforceable rights. ${ }^{269}$ Instead, the court "leapfrog[ged]" the issue, moving on to address the appropriate "remedy, or lack thereof, for a violation." 270 The appellate court found that "suppression is not warranted" because: I) it is not an appropriate remedy; 2) the VCCR does not provide for it explicitly; 3) refusing to adopt the exclusionary rule "promote[s] harmony in the interpretation of an international agreement[;]" and 4) Diemer failed to show he was prejudiced by the violation. ${ }^{271}$

The Massachusetts court went out of its way to enumerate reasons why it could not grant relief for a consular rights violation, lending a defensive tone to its opinion. ${ }^{272}$ The court added in a footnote, "[W]e are disheartened to learn that, on this occasion at least, Massachusetts has not acted in conformity with Article 36. It is reassuring, thus, to read in the amieus brief filed by the Attorney General that steps are being undertaken

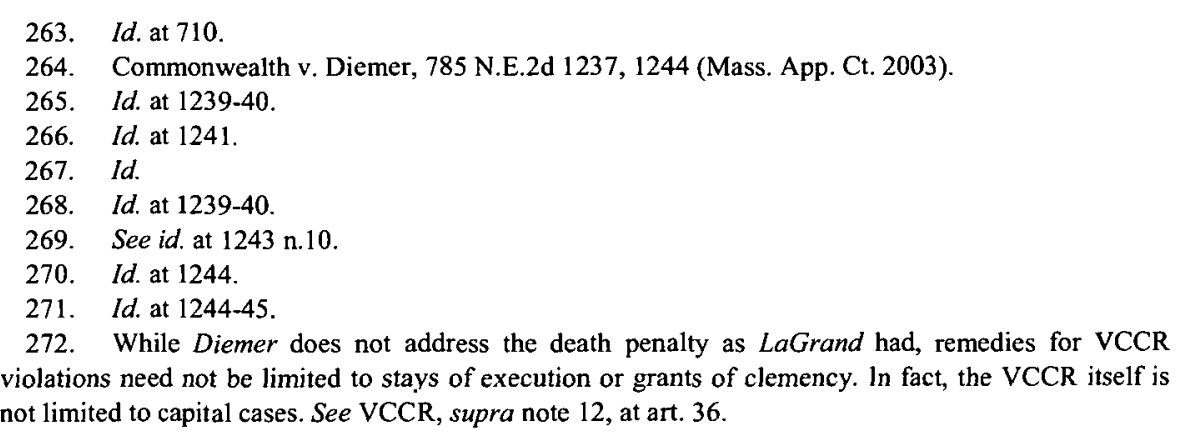


to address this issue in the future."273 The assurances that had led the ICJ to dilute its remedies were the same as those that led the Diemer court to withhold relief. Defendants whose rights have been violated suffer when international and domestic courts are lulled into deference through such assurances by the executive branches.

\section{c. Medellin}

In Medellin's wake, if and when U.S. appellate courts begin to hear VCCR claims, they must address several critical questions. First, courts will need to determine what weight, if any, the ICJ rulings in LaGrand and Avena should be given. Because the Supreme Court did not resolve this issue when it dodged Medellin, lower courts must now resolve the issue on their own, possibly leading to conflicting interpretations on the matter.

Second, the federal executive's decision to allow states to "give effect" to Avena may be read to give effect to all ICJ holdings, including the ICJ's more controversial rulings that the VCCR creates individually enforceable rights and that the procedural default rule cannot bar VCCR claims. The directive may settle the confusion and "leapfrogging" of the individual rights issue, though some courts may continue to find that the VCCR does not create individually enforceable rights regardless of what the ICJ held. Further, the fifty-one Avena defendants should theoretically have access to courts without the procedural default bar, though it remains unclear how cases for defendants in similar situations would be resolved.

One long-term implication may be the rejection of procedural default bars to all VCCR claims to ensure consistency. That some courts may not be inclined to provide such leniency to criminal defendants makes this an unlikely scenario, however. The Supreme Court may therefore be called upon to decide what weight, for example, Avena and LaGrand should have had on the Court of Criminal Appeals of Tennessee when it decided, in clear contradiction of the ICJ's holdings, that a German national's VCCR claims were procedurally barred under relevant state laws. ${ }^{274}$

Justice O'Connor may well be proved correct in predicting that the complex issues raised by Medellin "are bound to recur." 275 The Court may have bought itself some time, but at the expense of continued lower court confusion and disharmony, and continued inaction to cure VCCR violations for scores of foreigners sitting in U.S. prisons, some under sentence of death.

273. Diemer, 785 N.E.2d at 1246 n.13.

274. Cauthern v. State, 145 S.W.3d 571, 627 (Tenn. Crim. App. 2004).

275. Medellin II, 125 S. Ct. 2088, 2096 (2005) (O'Connor, J, dissenting). 


\section{B. Looking Forward to Curb Future VCCR Violations}

The executive and judicial branches actions can help remedy past VCCR violations and begin to prevent future violations from occurring. But the best long-term solution to addressing VCCR rights will come from state and federal legislatures, even if it is potentially slower and more cumbersome than executive or judicial action. Congress and state legislatures can set standards of conduct for police, prosecutors, and courts to guarantee effective remedies to foreign nationals facing serious criminal charges. Such legislative action may prove unlikely, however, given Congress's current hostility to foreign courts and countries. ${ }^{276}$ Further, voters hold state and federal legislatures accountable for their actions through the ballot box. In an era where public officials seeking election must show they are "tough on crime," enacting new laws that broaden defendants' rights may prove difficult.

\section{Adoption of Miranda-VCCR Rights}

Legislatures may choose to adopt the ICJ's suggestion and provide a Miranda-like warning to all individuals at the time of arrest. I suggest that a simple statement such as "if you are not a U.S. citizen, you have the right to have your consulate notified of your arrest" would satisfy the United States' VCCR obligations, Avena's "without delay" requirement, and domestic criminal laws. This statement can be appended to the current Miranda warning to create a new Miranda-VCCR warning. As a Delaware court explained in State v. Reyes,

[W] hen a foreign national is arrested, especially one who is unable to speak the language of the receiving State, it is likely that he will be unfamiliar with the receiving State's criminal justice system, and may be unable to defend himself, not just due to ignorance, but also due to possible discrimination based on his national origin. ${ }^{277}$

Adopting a Miranda-VCCR warning would clarify ambiguities in existing case law. The Reyes court concluded its VCCR analysis by noting, "a suspect may be interrogated only if he makes a voluntary, knowing, and intelligent waiver of his rights. The burden is on the State to prove by a preponderance of the evidence that the suspect waived his [VCCR] rights," which he did not do in that case. ${ }^{278}$ Thus, regardless of his having received his Miranda rights, the court granted his motion to suppress statements made after his arrest because law enforcement officers did not read him his

276. For the most amusing example of this, one need look no further than the House of Representative's renaming french fries "freedom fries." Jack Hitt, Honoring the Jaw-Dropping Achievements of the 108th Congress, 29 MOTHER JONES 52 (2004).

277. State v. Reyes, 740 A.2d 7, 14 (Del. Super. Ct. 1999), reargument denied, 1999 Del. Super. LEX1S 353 (Del. Super. Ct. Aug. 17, 1999).

278. Id. (footnote omitted). 
VCCR rights. ${ }^{279}$ Conversely, in State $v$. Jang, a New Jersey court held that where law enforcement had read the defendant his Miranda rights, no prejudice from a VCCR violation existed and no remedy was therefore warranted. ${ }^{280}$

That some, even many, suspects may not speak English, and thus not understand that their consular rights have just been read to them, does not justify refraining from adding a VCCR warning. A suspect that does not speak English well enough to understand his/her VCCR rights will also not understand his/her Miranda rights. Law enforcement already provides Miranda rights in different languages, whether verbally or in writing. ${ }^{281}$

Translating and adding a short nineteen-word phrase informing an arrestee of his VCCR rights should not pose an insurmountable burden. Indeed, the United States has already engaged in an effort to publish and distribute individual pocket cards for U.S. law enforcement officers, to better educate them of VCCR rights. ${ }^{282}$ These same assurances persuaded the ICJ to provide meek remedies for U.S. VCCR violations. Adding a strong, prophylactic measure to create a Miranda-VCCR warning strengthens the U.S. commitment to ending VCCR violations.

Ultimately, a Miranda-VCCR warning would be subject to the same limitations and criticisms of Miranda itself. A new Miranda-VCCR warning may "shackle" law enforcement, as critics contend Miranda does. ${ }^{283}$ But, as with Miranda, due process and fundamental rights concerns suggest that these "shackles" represent a wise and necessary tradeoff, particularly in light of the difficulties the United States finds itself in because of

\section{Id. at 8,14 .}

280. State v. Jang, 819 A.2d 9, 15 (N.J. Super. Ct. App. Div. 2003); see also United States v. Rodrigues, 68 F. Supp. 2d 178, 184 (E.D.N.Y. 1999). The court explained:

Although Rodrigues was not informed of his right to consular notification, he was given his Miranda warnings, which he indicated he understood and then waived. Prejudice has never been-nor could reasonably be-found in a case where a foreign national was given, understood, and waived his or her Miranda rights.

Id. (citation omitted).

281. See Commonwealth v. Almonte, 829 N.E.2d 1094, 1099 (Mass. 2005) ("Using a printed form in Spanish, the defendant was advised of his Miranda rights. The Miranda rights were read to the defendant as he looked at a copy of the same printed form."); Nguyen v. State, 605 S.E.2d 130, 131 (Ga. Ct. App. 2004) ("[U]sing a telephone Vietnamese interpreter, [the police] advised [Nguyen] of his Miranda rights . . .); Jang, 819 A.2d at 12 ("Defendant was also advised of his Miranda rights in both English and Korean. He read the Miranda card in Korean, wrote 'yes' next to each of the Miranda rights, and signed his name in English in the waiver portion of the Miranda form.") (footnote omitted).

282. LaGrand Judgment, 2001 1.C.J. 466, $511-12$ (June 27).

283. See Paul G. Cassell \& Richard Fowles, Handcuffing the Cops? A Thirty-Year Perspective on Miranda's Harmful Effects on Law Enforcement, 50 STAN. L. REv. 1055, 1132 (1998). The authors note:

Miranda may be the single most damaging blow inflicted on the nation's ability to fight crime in the last half century. In short, it appears that Miranda has, as its critics charge, handcuffed the cops. It is time to consider removing those shackles and regulating police interrogation in less costly ways. Id. 
the systematic failure of state and local law enforcement to obey the VCCR in the past. Further, even if adding a notification of VCCR rights "shackles" law enforcement efforts, the "shackles" come from a treaty which the United States has signed onto. ${ }^{284}$ Thus, a Miranda-VCCR warning only alerts a foreign national of the rights that the United States, through treaty, has already guaranteed. Congress can implement legislation tying a Miranda-VCCR warning to U.S. treaty obligations under the Constitution's Necessary and Proper Clause, ${ }^{285}$ thereby answering wouldbe critics who question the legitimacy of such actions.

A significant difference, however, may be that one often talks of U.S. citizens' rights when discussing the benefits of and problems with the Miranda warning, whereas with the VCCR, one invariably refers to foreign nationals' rights. And be it freedom fries or the fear that an unelected court sitting in Europe dictates U.S. law, this may represent a significant distinction from Miranda, which may in turn prevent the adoption of a prophylactic Miranda-VCCR warning.

\section{State Attempts to Comply with VCCR Requirements}

Several states have created statutes that implement notification schemes called for in the VCCR; significant steps, but short of a MirandaVCCR warning. In 1999, the California legislature required that foreign nationals or suspected foreign nationals receive their VCCR rights within two hours of arrest and booking. ${ }^{286}$ The legislature enacted this statute "to ensure that policy or procedure and training manuals incorporate [VCCR] language." 287 Later, in 2004, California revised Penal Code $\S 5028$ to incorporate consular rights. ${ }^{288}$ The revised statute reads:

Upon the request of a foreign consulate representing a nation that requires mandatory notification under Article 36 of the [VCCR] ..., the Department of Corrections shall provide the foreign consulate with a list of the names and locations of all inmates in its custody that have self-identified that nation as his or her place of birth. ${ }^{289}$

284. That President Bush withdrew from the Optional Protocol does not affect the United States' commitments to abide by the VCCR itself.

285. U.S. CONST. art. I, $\S 8$ ("The Congress shall have Power ... To make all Laws which shall be necessary and proper for carrying into Execution the... Powers vested by this Constitution in the Government of the United States.").

286. Cal. Penal Code $\S 834$ c(a)(1) (West Supp. 2005).

287. 1999 Cal. Legis. Serv. Ch. 268 (West 2005).

288. 2004 Cal. Legis. Serv. Ch. 924 (West 2005).

289. Cal. Penal Code $\S 5028$ (b) (West Supp. 2005). 
These statutes are especially important because California houses many foreign nationals and has the largest number of foreign nationals sentenced to death of any state. ${ }^{290}$

Other states have also adopted statutes that address the VCCR, but these laws do not always benefit the foreign national. In North Carolina, for example, the governor must notify the appropriate consular officials once police have determined that an individual is a foreign national. ${ }^{291}$ Oregon also requires consular notification in such a situation. ${ }^{292}$ But Oregon statutes may have no real immediate impact on defendants' rights because they require training for police to "[u]nderstand the requirements" of the VCCR and no more. ${ }^{293}$ But Oregon requires consular notification only by a "physician, nurse or qualified mental health professional" when the professional lcarns that the patient is a foreign national. ${ }^{294}$ The Oregon statute provides less protection than if it required notification by law enforcement generally. Foreign nationals solely seeking health care are unlikely to need access to their consuls, and perhaps a small subset of foreigners will come in contact with health professionals tangential to their law enforcement experience. Finally, Florida law states that failure to provide consular notification will neither constitute a defense to the crime nor be used as a basis to obtain the foreign national's discharge. ${ }^{295}$ These legislative actions range from protective (California) to hostile (Florida) and provide commendable first attempts to address VCCR violations at the state level. But with 18.5 million non-citizens residing in the United States ${ }^{296}$ and millions more visiting every year, the magnitude of the problem requires further legislative action.

\section{Other Possible Measures}

Legislatures may also wish to adopt one or all of the following other measures in addition to the Miranda-VCCR warning. First, Congress and state legislaturcs can exempt VCCR violations from the Death Penalty Reform Act and its state equivalents. This eliminates the procedural default rule's application to VCCR claims, while leaving its effect on other criminal appeals intact. Thus, cases currently pending in state and federal courts could be heard on the merits of their alleged VCCR violations rather than dismissed on procedural technicalities. Second, Congress and state

290. Forty-three of one hundred twenty condemned foreign citizcns are on death row in California. WARREN, supra note 25.

291. N.C. Gen. STAT. \& 122C-344 (2003).

292. Or. Rev. Stat. ANN. $§ 426.228$ (9)(a) (West 2005).

293. Or. Rev. Stat. AnN. $\$ 181.642$ (West 2005).

294. Or. Rev. Stat. ANN. $\$ 426.234$ (1)(e) (West 2005).

295. Fla. Stat. ANN. $\$ 901.26$ (West 2005).

296. U.S. Census Bureau, Profile of General Demographic Characteristics: 2000 tbl.DP1 (2000), available at http:/factfinder.census.gov/servlet/QTTable?_bm=y\&-geo_id=01000US\&qr_name=DEC_2000_SF1_U_DP1\&-ds_name $=$ DEC_2000_SF1_U. 
legislatures could adopt legislation similar to California Penal Code sections 5028(b) and 834(c) furthering U.S. compliance with treaty obligations by quantifying the "without delay" notification requirement. Such a step might then meet the ICJ's "without delay" requirement because California's 24-hour limit falls within the 40-hour delay found by the ICJ to be too long. Though twenty-four hours may also be too long, the ICJ would most likely look favorably upon federal and state statutes aimed at placing the United States in compliance with its foreign treaty obligations.

IV

IMPLICATIONS OF BREARD, LAGRAND, AND AVENA IN THE WAKE OF $M E D E L L I N$ AND AWAITING SANCHEZ-LLAMAS AND BUSTILLO

The ICJ has addressed U.S. violations of consular rights three times. Each time, the ICJ has grown bolder and stronger in its language, finding that the United States has violated foreign nationals' rights. The ICJ has, however, imposed meek remedies in two of its three Judgments, perhaps in acknowledgement of the political reality that neither the ICJ nor any international institution can enforce its decision. Thus, while each of the three decisions has built upon the strengths of its predecessors and has made acknowledging the ICJ's findings nearly inescapable, it remains within the United States' purview how specifically to implement the Judgments, if at all.

Breard, LaGrand, and Avena only affect Paraguay, Gcrmany and Mexico, respectively. Under a narrow reading of these cases, the thirty other States with foreign nationals on U.S. death rows must bring individual suits to seek proper reparations. But with President Bush's withdrawal from the Optional Protocol, that avenue has been effectively removed.

The ICJ has suggested that Avena can stand for more than the fiftyone named defendants in the case: "[T]he fact that in this case the Court's ruling has concerned only Mexican nationals cannot be taken to imply that the conclusions reached by it in the present Judgment do not apply to other foreign nationals finding themselves in similar situations in the United States." ${ }^{297}$ Indeed, the Supreme Court recently granted certiorari to hear the VCCR claims of a Honduran citizen based on Avena. ${ }^{298}$ This action may signal that the Court considers the ICJ's rulings to apply to the VCCR generally and not limited to three specific countries and their citizens. On the other hand, the Court may use Bustillo as a vehiele to proclaim that Avena does not extend further than to the fifty-one named defendants in the case.

The Supreme Court should not have washed its hands of Medellin. Even after President Bush declared that states shall provide "review and

297. Avena, 2004 1.C.J.128, ๆ 151 (Mar. 31).

298. See Questions Presented, supra note 10 (granting certiorari in Bustillo v, Johnson, No. 05-51, 2005 WL 2922486 (Nov. 7, 2005)). 
reconsideration" for the fifty-one Avena defendants, the significant legal and political issues raised in Medellin were bound to return, and now have. By taking cases from defendants not named in Avena, the Court may seek to sidestep thorny separation of powers and federalism issues the Bush directive raised. If the Court does not dismiss these cases again, they present opportunities for it to set a clear path for lower courts to follow, avoiding the confusion similar to that seen in lower courts following Breard, LaGrand, and Avena. ${ }^{299}$ And, it would signal an end to the Court's inactivity in the wake of the ICJ's activism.

299. State v. Cauthern, 145 S.W.3d 571, 627 (Tenn. Crim. App. 2004) (noting "the lack of direction from the United States Supreme Court" on how best to interpret the VCCR in light of LaGrand). 
